\title{
Decentralized Valorization of Residual Flows as an Alternative to the Traditional Urban Waste Management System: The Case of Peñalolén in Santiago de Chile
}

\author{
Jeltsje de Kraker ${ }^{1,2}$, Katarzyna Kujawa-Roeleveld ${ }^{1,3}$, Marcelo J. Villena ${ }^{2}$ and \\ Claudia Pabón-Pereira 1,2,*iD \\ 1 Sub-Department of Environmental Technology, Wageningen University and Research, P.O. Box 17, \\ 6700 AA Wageningen, The Netherlands; jelske.dekraker@wur.nl (J.d.K.); \\ katarzyna.kujawa-roeleveld@wur.nl (K.K.-R.) \\ 2 Facultad de Ingeniería y Ciencias, Universidad Adolfo Ibáñez, Diagonal Las Torres 2640 Peñalolén, Santiago \\ de Chile, Chile; marcelo.villena@uai.cl \\ 3 LeAF, Bornse Weilanden 9, 6708 WG Wageningen, The Netherlands \\ * Correspondence: Claudia.Pabon@uai.cl
}

Received: 17 September 2019; Accepted: 21 October 2019; Published: 6 November 2019

\begin{abstract}
Urban residual flows contain significant amounts of valuable nutrients, which, if recovered, could serve as input for the own city needs or those of its immediate surroundings. In this study, the possibilities for decentralized recovery of nutrient rich residual flows in Santiago, Chile, are studied by means of a case study considering technical and socio-economic criteria. In particular, we calculate circularity indicators for organic matter $(\mathrm{OM})$, nitrogen $(\mathrm{N})$, and phosphorus $(\mathrm{P})$ and cost-benefits of household and community on-site technological alternatives. Kitchen waste (KW) and garden residues (GR) as well as urine were considered as system inputs whereas urban agriculture, municipality green, or peri-urban agriculture were the considered destinations for nutrients recovered. The technologies studied were anaerobic digestion, vermicomposting, and composting, while urine storage and struvite precipitation were considered for nutrient recovery from urine. Material flow analysis was used to visualize the inputs and outputs of the baseline situation (the traditional urban waste management system), and of the different household and municipality resource recovery scenarios (the decentralized valorization systems). Our findings show that decentralized valorization of KW and GR are a clear win-win policy, since they can not only produce important environmental benefits for the city in the long run, but also important cost savings considering the landfill fees and residues transportation of the current centralized waste management system.
\end{abstract}

Keywords: waste management; circular metabolism; decentralized valorization; nutrient recovery; material flow analysis

\section{Introduction}

Urban metabolism refers to the accounting of energy and material fluxes of a city or any inhabited core; the concept serves as a framework for analyzing its inputs and outputs, often focusing on energy, water, and nutrients flows. When studying urban metabolism, it is usually the aim to understand current linear resource management strategies in the cities characterized by high resource demand and polluting discharges of waste streams, and propose alternative closed-loop systems where resources are efficiently used within urban boundaries with a restorative perspective [1,2].

Of particular interest are nutrient transformations, as cities can substantially impact ecosystem cycles through the fluxes of elements such as carbon $(\mathrm{C})$, nitrogen $(\mathrm{N})$, and phosphorus $(\mathrm{P})$. The city, 
as an organism, intakes those elements via food inputs coming mostly from external agricultural sources, which, after consumed, transform partially into unwanted by-products i.e., solid waste or human excreta [1]. Within the linear approach, these flows are usually directed towards end-of pipe solutions such as landfills or wastewater treatment plants (WWTP) where they are contained or partially treated and recovered, thereby still causing unwanted emissions to be released into the natural environment. At the same time, on the supply side, these nutrients need to be brought to the agricultural sector and/or urban agriculture (UA) where food consumed in the city is being produced, causing negative impacts, particularly resource depletion (i.e., phosphorus) and indirect energy consumption (i.e., artificial nitrogen fertilizer production) [3-6].

Alternative destinations for these outflows can be found, such as: City green spaces, accelerated regeneration of natural disaster sites (fires, floods), erosion-prone hillsides in the city, selling the nutrients to external buyers, and/or for UA [5,7]. In particular, UA is a suitable and increasingly popular destination for recovered nutrients as it allows for closing cycles locally, reducing transport distances for residues, fertilizers, and food, offering many advantages for citizens (e.g., increased green space), and avoiding fossil-based artificial fertilizers (see [7]).

Despite the potential for closing nutrient, water, or energy flows, in practice, the implications of closing cycles in urban systems is not evident, due in part to the lack of information about the possibilities in matching demand and supply considering the quantity and quality of flows, its time and space availability, as well as user practices and disposition for changing household practices.

Circular economy is gaining attention in Chile, both at private and public institutions. At the Chilean Ministry of Environment, the recently created circular economy office is designing a national strategy for the separation and recovery of organic solid waste (OSW) [8]. In Chile, the amount of generated municipal solid waste (MSW) is increasing rapidly at a rate of $27 \%$ per decade [9], OSW being the largest fraction (48\%), only $10 \%$ valorized (mainly through composting or vermicomposting) $[9,10]$. Hence, separate, value-oriented processing of this fraction is seen as a strategy for potentially reducing the negative impacts of current disposal. In addition, it is expected that when OSW are valorized at the source, cost savings could be achieved for municipalities avoiding landfill fees and residues transportation.

The largest production of MSW in Chile takes place in the Metropolitan Region of Santiago (MRS), where $40.1 \%$ of the country's inhabitants live, i.e., 6,061,185 [10,11]. About $98 \%$ of the domestic residues are collected and disposed in three sanitary landfills where no nutrient recovery takes place [12]. Regarding sanitation, there is 100\% sewage coverage and treatment of the wastewater and $44 \%$ out of the near 75.555 tons/day residual sludge produced are partially recovered for agricultural application [13].

Beyond current centralized schemes, decentralized OSW management alternatives are of interest in this context. Municipality onsite alternatives for waste management present opportunities, such as the higher control and potential economies of scale, but also challenges including lack of suitable land, different types of permits required, and investment costs [14]. Domestic alternatives are also of interest; they reduce the need for scarce municipal land and operational costs. In both cases, it is important to consider the willingness and possibilities of inhabitants, as well as the technical and economic feasibility of the options and their environmental implications. The lack of information regarding the previous hinders policy decisions in the domain of OSW management but also related ones in the fields of urban landscape management, sustainable (peri) UA, and new sustainability investments.

This study addresses the potential of closing of nutrient cycles (C, N, P) through the decentralized technological valorization of OSW and urine in Peñalolén municipality in Santiago de Chile considering household and municipality on-site scenarios and end-use of products at different scales. The overall objective is to assess circularity, costs, and benefits of these non-conventional alternatives so policy makers can have an indication that can serve for guiding the new OSW policy decisions.

Urine is considered for completeness of the results as it contains the highest levels of $\mathrm{N}$ and $\mathrm{P}$ among household generated residual flows [15]. Peñalolén municipality is chosen as a case study, 
because it has been one of the pioneer municipalities piloting environmental education as well as OSW valorization and reuse in the MRS, plus it shows a socio-economic demographic distribution similar to that of the overall Santiago [16,17].

\section{Methodology}

\subsection{Overall Approach}

Different methodologies exist for analyzing urban metabolism, with most of them taking the material flow analysis (MFA) as a departing point [18]. In this study, the urban harvest approach (UHA) is the overarching methodological framework used. The UHA is a method used for analyzing urban metabolism, which allows comparing different resource recovery measures and technologies and their impacts on urban self-sufficiency. UHA can be applied to different resources, e.g., water, energy, nutrients [19].

The first step of UHA is a baseline assessment, which in our case is built using direct information gathered from interviews to local families, as well as studies and previous research. MFA is used then to map the information collected, in terms of processes, stocks, and input and output flows.

The household supply and demand of nutrients is gathered via socio-economically segmented interviews and scientific literature. Inhabitants of Peñalolén were interviewed in order to assess quantitative and qualitative aspects relevant to nutrient flows including food intake, land availability and use, municipality gardens and fertilizer use, and disposition, through multiple open and closed questions. Peñalolén accounts for 253,175 inhabitants, which is about $4 \%$ of the total inhabitants in Santiago. In particular, a total of 70 interviews were conducted among different socioeconomic groups (SEG) present in the municipality.

After the baseline scenario is drawn, alternative scenarios are developed focusing on recovering nutrients from waste streams. UHA proposes three ways to close cycles: Demand minimization, output minimization, and multi-sourcing. In this study, output minimization is the main principle applied, although the principle of resource minimization is also applied when calculating the amount of nutrients demanded by the urban processes. Four technologies are assessed as a means to achieve this objective, these are: (i) Composting, (ii) vermicomposting, (iii) struvite recovery (from urine), and (iv) anaerobic digestion. The choice for these technologies is based on their applicability in decentralized settings either at house or municipality level, plus their availability and already existing local knowledge for most of them. The alternative decentralized scenarios are then drawn based on several (combinations of) the mentioned technologies and are quantified using MFA. Finally, these scenarios are compared by means of a set of indicators aimed at measuring both the degree of circularity achieved in terms of the studied nutrients and the economic output, i.e., costs and benefits of the alternatives.

\subsection{Material Flow Analysis}

Within an MFA, the goal and scope, as well as system boundaries, processes, and flows of goods are defined [20]. We define the goal of this study as to assess circularity and cost-benefits of resource recovery from domestic OSW in a Peñalolén municipality by means of decentralized treatments units at the household or municipality level. System boundaries, in our case, are established firstly and most importantly at the household level where all information regarding resource production and onsite demand is gathered and systematized. Domestic organic waste streams are the main flows considered in this study, particularly OSW and urine. The feces stream is excluded because of the public aversion to its collection and reuse, plus foreseen legislation constraints. While urine is currently not separately collected and reused either, it is expected that public opinion will be more favorable in this case. This assumption is tested through interviews. The grey-water flow is also not assessed due to its low concentrations of nutrients, which are the main focus of this study. The functional unit for calculations is kilograms per household per year $[\mathrm{kg} / \mathrm{hh} / \mathrm{y}]$ (see Figure 1). 


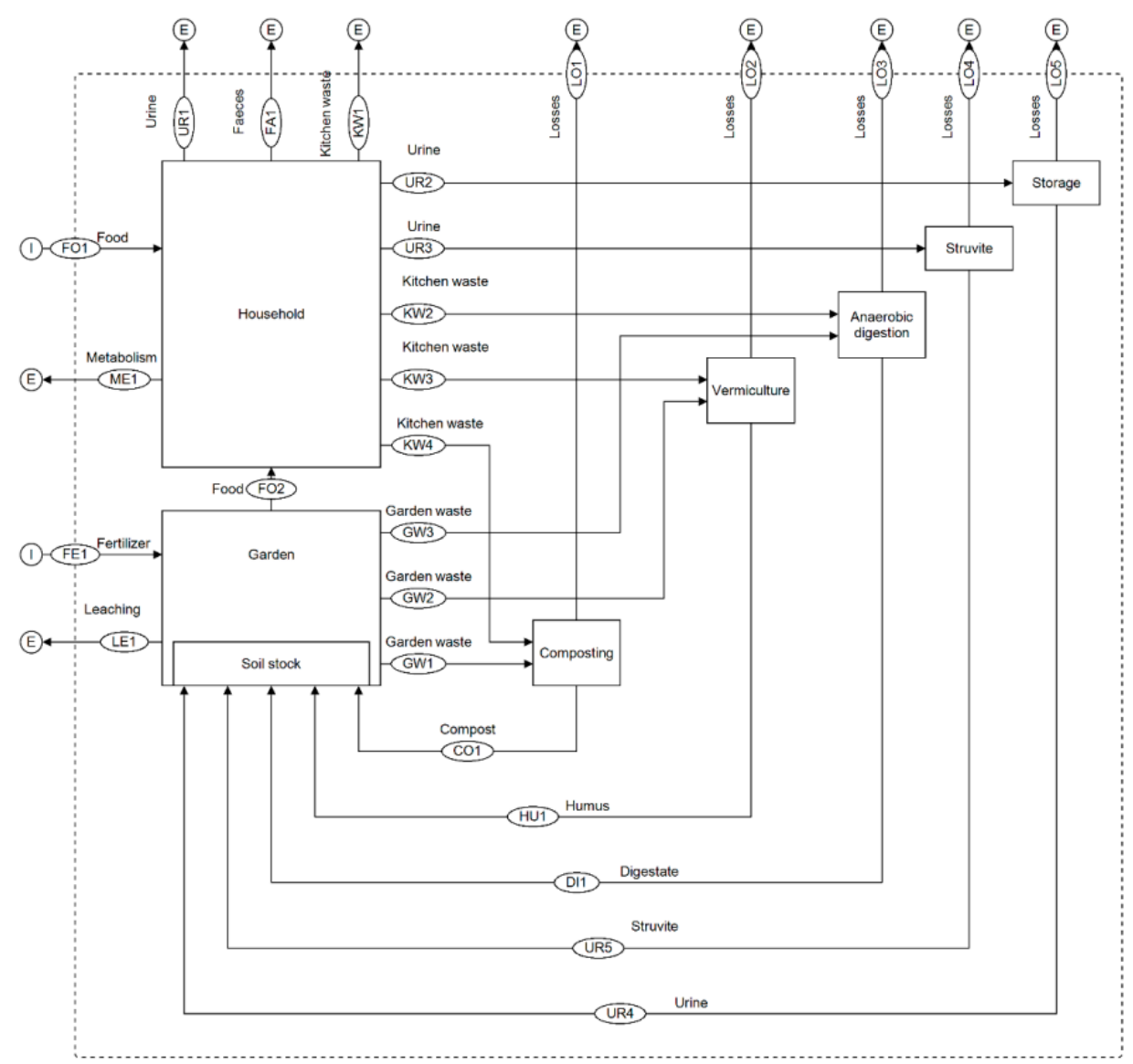

Figure 1. Material flow analysis (MFA) model showing the processes and flows involved at the household level affecting N, P, and organic matter (OM) supply.

The system boundaries are then enlarged at two levels more considering different output destinations for the obtained valorized resources. These levels also relate to the indicators used to compare scenarios as shown in Figure 2. The closest level investigated for nutrient recovery is the household garden, the second level considers Peñalolén urban green and the third level includes agricultural areas within the MRS. The use of local residues to cover the demand from other municipalities is not included as it is assumed that they can also use their own residues for their green areas and UA. Outside of the system boundaries, the sources for resources imported such as food streams, and the current destination for OSW and excreta, i.e., landfills and WWTP, are located. 


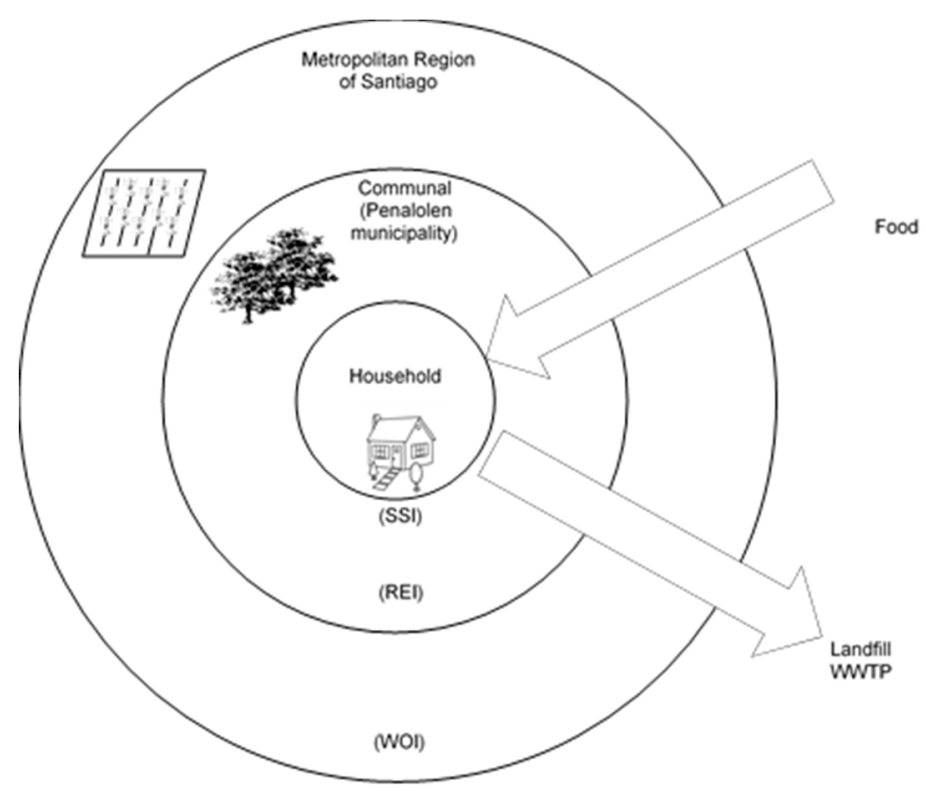

Figure 2. System definition with three levels of analysis: Household, Peñalolén urban green, and nearby agriculture, and their corresponding indicators: Self-sufficiency index (SSI), resource recovery index (REI), and waste output index (WOI).

The software used to systematize the MFA in this study is STAN (substance flow analysis) from Vienna University. STAN is a widely used, free software that helps to perform material flow analysis according to the Austrian standard ÖNorm S 2096 that concerns application of MFA in waste management.

\subsection{System Evaluation}

The developed technological options are compared by means of resource recovery and economic indicators. Firstly, the self-sufficiency index (SSI) evaluates to what extent self-sufficiency with regard to the nutrients for garden fertilization can be achieved if the whole garden would be used for food production at the household level. SSI $=0$ indicates full local self-sufficiency, SSI $=1$ indicates zero local nutrient production, and SSI $<0$ indicates the nutrient production is bigger than the local demand.

$$
S S I=\frac{D-I_{p}}{D}
$$

where demand (D) and internal production $\left(\mathrm{I}_{\mathrm{p}}\right)$ are in $\mathrm{kg} / \mathrm{hh} / \mathrm{y}$. Scenarios at the household level are compared based on the SSI.

Secondly, the resource export index (REI) shows to what extent local household nutrient production exceeds both individual household demand plus the demand by the green areas in Peñalolén Municipality. REI $>0$ indicates that the demand is exceeded and nutrients need to be exported out from the municipality and REI $<0$ means more nutrients need to be imported.

$$
R E I=\frac{E_{r}}{D}=\frac{T_{i}-D}{D}
$$

where total input $\left(\mathrm{T}_{\mathrm{i}}\right)$, demand $(\mathrm{D})$, and exportable resources $\left(\mathrm{E}_{\mathrm{r}}\right)$ are in $\mathrm{kg} / \mathrm{hh} / \mathrm{y}$.

Thirdly, the waste output index (WOI) is the final indicator used in this study. For this indicator, the nutrient system boundaries are expanded considering that from the amount of nutrients available or total input $\left(\mathrm{T}_{\mathrm{i}}\right)$, nutrients that can be disposed in nearby agriculture within the MRS as well as those that go to households and urban greens within Peñalolén municipality are kept within the system as considered as recycled (R), whereas nutrients going to the landfills or lost during treatment are 
regarded as the waste exported $\left(\mathrm{W}_{\mathrm{E}}\right)$. WOI $=-1$ indicates linear metabolism and WOI $=0$ indicates complete absence of output; thus, a fully circular system.

$$
W O I=-\frac{W_{E}}{T_{i}}=\frac{T_{i}-R}{T_{i}}
$$

Finally, a cost-benefit analysis is performed for each of the scenarios, considering the changes in wellbeing, expressed in monetary terms, for the society as a whole. As is customary in social appraisal of projects, the consumer surplus of the situation without the project/policy is contrasted with the consumer surplus of the situation with project/policy; see for example [20]. If the gains in consumer surplus as a product of the project/policy is greater than the investment, the project must be carried out because it is efficient in economic terms.

In this case, the cost of the traditional urban waste management system (TUWMS) per household is compared with the cost of the decentralized valorization of residual flows (DVRF) per household. Obviously, the comparison is carried out only for the OSW being treated. Besides, the situation with the decentralized valorization presents also economic benefits that are duly accounted for.

In particular, the economic attractiveness of scenarios will be assessed based on the net present value (NPV) and payback period (PP). The NPV evaluates if the projected earnings generated by a project or investment (in present value) exceeds, or not, the anticipated costs (also in present value) (Equation (4)). A positive NPV represents a project that is worth investing in considering economic gains.

$$
N P V=\sum_{t=0}^{N} \frac{C F_{t}}{(1+r)^{t}}-I_{0}
$$

where CFt is net cash flow during period $t$ and Io is total initial investment costs, both in $\$$ (USD), $r$ is social discount rate, and $\mathrm{N}$ is the number of time periods. CFt consists of the cost savings of the municipal authority considering the decentralized scheme (Cost TUWMS - Cost DVRF), plus the profit generated by each project considering the valorization of the residuals (Benf $D V R F$ ). This calculation is estimated based on the costs savings and benefits per household per year perceived by society (see Equations (5)).

$$
C F t=\text { Cost TUWMS }- \text { Cost DVRF + Benf DVRF }
$$

In the same way, the payback period (PP) of the investment informs of the amount of years it will take to earn back the investment with yearly profits.

Current costs for domestic OSW management were provided by the municipality. Benefits include profits from the sale of compost, vermicompost, digestate, struvite, and/or biogas or savings from not having to buy those resources The price for digestate, urine, and struvite are determined based on their nutrient content following a pricing method proposed by the UK Environment Agency [21], which considers market prices for commercial alternatives. This is the reason that different prices are considered, for example, for digestate depending on its reuse destination, as retail prices differ significantly from those for agriculture. Possible benefits from increased productivity in food grown using the recovered nutrients is not included. Costs included in the analysis are operation, transport, and fees. Technology data for the analysis at the household level is taken from commercially available Chilean technology, whereas at the municipality level, since full-scale facilities are lacking, calculations were made using the literature describing projects of similar size and adjusted for local costs [22-25]. Since the analysis is made from the perspective of costs for the municipality, the discount rate (r) is assumed to be $8 \%$, a usual rate for social projects. The project time $\mathrm{N}$ considered for the economic evaluation is 10 years. Municipal savings considered include the landfill fee and transport to landfill when in the case of OSW. In the scenarios that include only resource recovery from urine, there are no such savings. 
In the case of urine, as residents are connected to the sewer system and they pay a tariff proportional to the drinking water consumed, cost savings are not considered when recycling urine, and hence, an NPV of household is simply estimated by a cash flow equal to the benefits minus the cost of each technology considered.

Even though we are performing a cost-benefit analysis using private prices, it is important to remark that the most important benefits of the decentralized valorization of residual flows are the reduction of negative externalities and the production of several positive externalities. However, the estimation of externalities are beyond the scope of this research.

\subsection{Baseline Description}

\subsubsection{Nutrient Inputs}

Nutrients come into the household system through daily food intake (DFI). Muñoz et al. [26] performed a total diet study for Santiago's population, which showed an average total DFI per person of $2237 \mathrm{~g}$, of which $484 \mathrm{~g}$ correspond to fruit and vegetables. From the interviews conducted, an average vegetable and fruit consumption of $320 \mathrm{~g} / \mathrm{p} / \mathrm{d}$ was assessed; since this number is below the recommended amount (i.e., $450 \mathrm{~g} / \mathrm{p} / \mathrm{d}$ [27]), the value by Munoz was considered to be target consumption. The average household assessed in the interviews was 4 inhabitants, which coincides with the official average household for the municipality [28].

Food composition was accounted using different literature sources. Protein and phosphorus contents of the consumed goods were obtained from the United States Department of Agriculture database [29]. The total amount of $\mathrm{N}$ (including non-protein $\mathrm{N}$ ) in the food can be estimated by dividing the amount of protein by a conversion factor of $4.4[30,31]$. To calculate the OM from food intake, the average OM content per food group is taken from the literature [32-41].

\subsubsection{OSW Production and Characterization}

In order to quantify and characterize the residues flows, a study of the Chilean National Environmental Committee (CONAMA) on the characterization of domestic residues in Santiago is used [41]. This research also estimates the fraction of KW and GR, these fractions are then applied to the $84,773 \mathrm{t} / \mathrm{y}$ domestic solid waste production in the Peñalolén Municipality [14], considering a population size of 253,175 [17] (see Table 1).

In the current situation, there is no separate collection of OSW within the municipality, and the only amount recovered is that going to the local program EcoParque Peñalolén-UAI. This is a collaborative applied research initiative carried in association with Universidad Adolfo Ibañez, where circular urban metabolism, organic residues valorization, as well as urban agriculture are researched and promoted [42]. Yearly, an average 170 tons of market waste are treated there, while all other OSW collected are disposed in landfills. The collection, transport, and disposal of residues in 2016 cost the municipality 30,605 million CLP (38.9 million EUR or 43 million USD), which is 120,883 CLP per inhabitant (154 EUR or 170 USD) [10,14] (see Table 1).

Table 1. Mean amounts and composition of food, urine, feces, kitchen waste (KW), and garden residues (GR) for the average household in Penalolén.

\begin{tabular}{ccccccc}
\hline & Unit & Food & Urine & Faeces & KW & GR \\
\hline mass & $\mathrm{kg} / \mathrm{hh} / \mathrm{d}$ & 12.8 & 4.8 & 0.84 & 1.76 & 0.2 \\
\hline $\mathrm{TN}$ & $\mathrm{g} / \mathrm{hh} / \mathrm{d}$ & 97.2 & 75.2 & 10.4 & 11.6 & 0.8 \\
\hline $\mathrm{TP}$ & $\mathrm{g} / \mathrm{hh} / \mathrm{d}$ & 8.2 & 4.28 & 1.92 & 2 & 0.16 \\
\hline $\mathrm{OM}$ & $\mathrm{g} / \mathrm{hh} / \mathrm{d}$ & 2196 & 35.2 & 180 & 440 & 68
\end{tabular}

$\mathrm{TN}=$ total nitrogen; $\mathrm{TP}=$ total phosphorus; $\mathrm{OM}=$ organic matter; $\mathrm{KW}=$ kitchen waste; $\mathrm{GR}$ = garden residues [43-51]. 


\subsubsection{Current Resource (Re) Use Practices}

It was found that $68 \%$ of the interviewed inhabitants own a garden and already $44 \%$ of them use it (partly) to grow food. Further, $76 \%$ of the inhabitants would like to participate in growing (more) foods, indicating 'a lack of space' is the most important reason to not grow food at the moment. About half of these interested inhabitants would prefer a communal system and half an individual lots system. The remaining $24 \%$ mention 'a lack of time' as the most important reason for not willing to grow their own food. The average garden size assessed was $16 \mathrm{~m}^{2}$, although the deviation is very high, with the smallest being $3 \mathrm{~m}^{2}$ and the biggest being $54 \mathrm{~m}^{2}$.

The variety (not more than six different types of food including herbs per garden) and amounts (maximum dedicated space of $6.2 \mathrm{~m}^{2}$ and an average of $2.5 \mathrm{~m}^{2}$ ) are minimal compared to total food intake, i.e., $4726 \mathrm{~kg} / \mathrm{hh} / \mathrm{y}$ food intake versus $12 \mathrm{~kg} / \mathrm{hh} / \mathrm{y}$ food production on $2.5 \mathrm{~m}^{2}$ [52]. Therefore, in the baseline scenario, there is no food accounted as produced in the gardens.

Compost is both the fertilizer that is used most frequently (by inhabitants currently growing food) and the most preferred option (by everyone interested in growing food). However, twice as many people use compost purchased from retailers as those using home-made compost. Quantitative fertilizer use information provided by interviewees was not conclusive and therefore was not considered.

Since less than $10 \%$ of the interviewees' produces compost, recycling of KW and GR is not part of the baseline and those streams go to a landfill. Urine and feces go to the WWTP.

Only $20 \%$ of interviewees are positively disposed towards producing compost at home $(30 \%$ negative, 50\% unknown). Reasons mentioned are either a 'lack of space' or 'lack of knowledge' and in one case, the possibility of 'attracting pests'. Furthermore, $63 \%$ of inhabitants are positively disposed towards using urine. Those inhabitants that are not, give 'lack of knowledge' (2/3) and 'hygiene' (1/3) as reasons.

Urine and feces mass and COD loads were calculated based on the literature $[7,43]$. N and P content are calculated considering the food intake, as none is lost during metabolism [7,15], and they lie within the range of $\mathrm{N}$ and $\mathrm{P}$ concentrations found elsewhere [53]. The difference between food intake and the urine, feces, and KW flows for the mass and OM are assumed to be the result of human metabolism. Table 1 shows the summary amount of the input flows calculated for the average inhabitant.

\subsubsection{Resource Demand}

Reusing the resources produced from households either in urban gardens, urban green areas, or agriculture requires knowledge and assumptions about demand size, fertilization regime, and nutrient availability.

Regarding the nutrient demand at household level, the average size of the household garden is $16 \mathrm{~m}^{2}$ (see Section 3.1), while at the municipal level, the area considered is $3.6 \mathrm{~m}^{2} / \mathrm{p}$, which is the size of the municipality green in Peñalolén [54].

As there is no information available on current fertilization in gardens or urban green, fertilization demand is based on equilibrium fertilization. Equilibrium fertilization is a fertilization regime that takes into account the plant nutrient uptake to determine the nutrient demand and is used as a way to establish a minimized demand within the UHA [7]. For equilibrium fertilization, one would look at the biologically available $\mathrm{N}$ and $\mathrm{P}$ in the fertilizer and compare this to the $\mathrm{N}: \mathrm{P}$ of the crop in question or the average value if the crop is unknown. An assessment of the $\mathrm{N}$ and P content of the total fresh matter of 22 common horticultural crops by Fink et al. [52] found an average N:P of 6.3; within a range of 4.3 to 8.5 , this value is then considered here as average demand.

Regarding nutrient availability, considering that $\mathrm{P}$ can be quickly fixed into stable, unavailable forms in the soil resulting in a low plant uptake efficiency and the unavailable fraction of $\mathrm{P}$ (also $\mathrm{N}$ ) will mineralize and become available over time [55], in this study, the available nutrient input is used to determine short-term satisfaction of short-term nutrient demand, and the total nutrient input is used for the long-term demand. 


\subsection{Resource Recovery Options}

Several options exist to treat OSW streams and recover nutrients. The technologies assessed in this paper are composting, vermicomposting, and anaerobic digestion for garden and kitchen waste and urine storage and struvite precipitation for urine.

\subsubsection{Organic Residues Treatment}

Composting is considered to be performed using KW and GR in open pile systems with manual turning. The optimum C: $\mathrm{N}$ for a composting process is 20-30:1; a higher ratio results in N immobilization in the initial phase, lowering the degradation rate due to suboptimal bacterial growth. A lower ratio results in the release of mineral $\mathrm{N}$ early on in the process, causing odors [56] While P losses are minimal at 3\%, gaseous $\mathrm{N}$ losses can be substantial [57]. The exact amount of $\mathrm{N}$ and OM losses depend on substrate composition and process conditions. Since the average composition of garden and kitchen waste in Peñalolén is unknown, an average loss of $45 \%$ for $\mathrm{N}$ is considered [58-62] and 33\% for OM $[58,60,61,63]$. Of the total amount of nutrients present in the compost, $10 \%$ of the $\mathrm{N}$ and $50 \%$ of $\mathrm{P}$ is in available form $[7,64]$. Through composting, the mass is reduced by about $50 \%$ [65].

Mass loss and $\mathrm{P}$ loss and availability after vermicomposting are the same as for regular composting [60,65]. However, due to the worm activity, much less OM remains: 37\% [60]. There are also slightly higher $\mathrm{N}$ losses, $51 \%$, but of the remaining $\mathrm{N}$, more is present in available form: $24 \%[60,66]$. No worm harvesting is considered.

After anaerobic digestion (AD), both the effluent and sludge can be used for fertilization. During digestion, biogas, which consists of $\mathrm{CH}_{4}$ and $\mathrm{CO}_{2}$, is produced. Considering an average biogas production from domestic residues of $0.55 \mathrm{~m}^{3} / \mathrm{kg}$ volatile solids (VS) with $75 \%$ methane content, there is a $13 \%$ mass reduction [67]. The COD content of sludge (19\% of input) and effluent ( $27 \%$ of input) are assumed to have a 1.4 COD to OM ratio [7]. No $\mathrm{N}$ and $\mathrm{P}$ are lost and the availability of these nutrients after $\mathrm{AD}$ is considered to be, on average, $18 \%$ for $\mathrm{N}$ and $45 \%$ for $\mathrm{P}$ [68]

\subsubsection{Urine Treatment}

Urine is assumed to be separately collected with passive urine-diverting toilet devices, where, maximally, $75 \%$ of the urine is recovered. During storage, the OM degrades to a high degree, leaving only $27 \%$ after one year [7]. The urine is collected and stored in sealed tanks to prevent losses of ammonia. All nutrients are thus conserved [7]. Stored urine is a quick fertilizer and most $\mathrm{N}$ and $\mathrm{P}$ are expected to be present in mineralized form [69].

Struvite $\left(\mathrm{MgNH}_{4} \mathrm{PO}_{4} \cdot 6 \mathrm{H}_{2} \mathrm{O} ; \mathrm{MAP}\right)$ precipitation has been proposed and implemented for recovering both ammonia and phosphate from human urine [70-73]. Struvite is a white crystalline mineral that includes equal molar amounts of magnesium, ammonia, and phosphate. The recommended operating $\mathrm{pH}$ range is $8.5-9.5$. With struvite precipitation, $85 \%$ of the $\mathrm{P}$ can be recovered while $\mathrm{N}$ can be recovered with a molar ratio 1:1 $\mathrm{NH}_{4}$ to $\mathrm{PO}_{4}$ or $0.46 \mathrm{~N}$ to $\mathrm{P}[74,75]$. Struvite obtained from urine is a clean fertilizer, does not contain any $\mathrm{OM}$, and has a negligible concentration of micropollutants and metals [76]. The possible presence of pathogens can be eliminated e.g., by air-drying [77]. Although struvite is a slow-release fertilizer, all $\mathrm{N}$ and $\mathrm{P}$ is present in biologically available form [24,74].

\section{Results}

\subsection{Baseline MFA}

The resulting baseline MFA is shown in Figure 3; flows are presented in total mass and also OM, $\mathrm{N}$, and P. KW represents, in mass, $641 \mathrm{~kg} / \mathrm{hh} / \mathrm{y}$, which is $24 \%$ of total, however it constitutes the highest OM outflow, $160 \mathrm{~kg} / \mathrm{hh} / \mathrm{y}$ or $67 \%$, whereas its $\mathrm{N}$ and P content represents $12 \%$ and $24 \%$ of the total nutrient output. As expected, urine represents the biggest nutrient output with $77.5 \%$ and $52 \%$ of $\mathrm{N}$ and $\mathrm{P}$, respectively. There is potential to cover the garden demand of nutrients, which are shown as negative flows in the figure. 

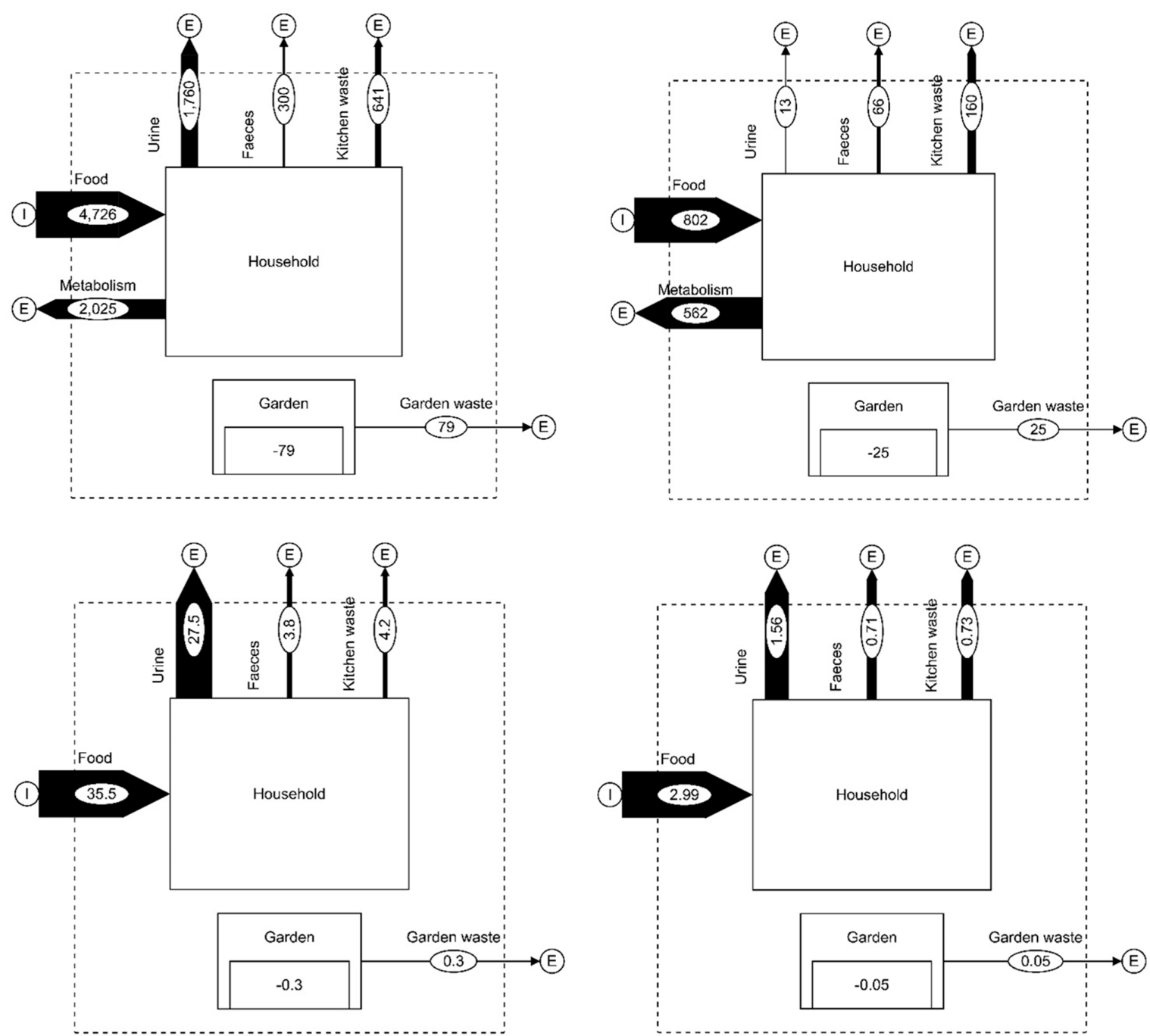

Figure 3. Baseline material flow analysis (MFA) for an average household in Peñalolén; each figure represents different material flows (from left to right and top to bottom): Mass, organic matter, nitrogen, and phosphorus in $\mathrm{kg} / \mathrm{hh} / \mathrm{y}$.

\subsection{Alternative Scenarios}

\subsubsection{Household on-Site Scenarios}

At the household level, KW and GR are assumed to be treated using AD in scenario 1 or vermicomposting in scenario 2 . Resources are recovered from urine with urine storage as the only valorization technique in scenario 3. Compost is considered unsuitable to treat residues at the household level given the lack of carbon-rich material required to equilibrate $\mathrm{C} / \mathrm{N}$ and humidity, i.e., GR fraction is too small and composition unsuitable to compensate for $\mathrm{KW}$ composition. Vermicomposting is then preferred as it requires less carbon material and hand labor, plus this is the technology currently promoted by the Peñalolén municipality within a pilot initiative for house on-site organic waste treatment. Struvite precipitation is regarded as impractical for an individual household. In the three scenarios, it is considered that inhabitants reuse the harvested resources from waste streams in their own gardens for growing food.

Taking into account the average yield of fruit/vegetable produce per ha, including consumable and non-consumable parts, the new GR production is $49 \mathrm{~kg} / \mathrm{hh} / \mathrm{y}$ [52]. This GR flow is still small compared to the KW flow of $641 \mathrm{~kg} / \mathrm{hh} / \mathrm{y}$ and it is added either to the vermicomposter or the biodigester. For 
all three scenarios, the composition of the final product containing nutrients is calculated as shown in Table 2, following the assumptions mentioned in Section 3.2.

Table 2. Amount and composition of the digestate, vermicompost, and stored urine that can be produced in one year by an average household in Peñalolén.

\begin{tabular}{cccccccc}
\hline & Unit & Mass & TP & av. $\mathbf{P}$ & TN & av. $\mathbf{~}$ & OM \\
\hline Digestate & $\mathrm{kg} / \mathrm{hh} / \mathrm{y}$ & 600 & 0.75 & 0.34 & 4.3 & 0.8 & 45 \\
\hline Vermicompost & $\mathrm{kg} / \mathrm{hh} / \mathrm{y}$ & 345 & 0.73 & 0.37 & 2.1 & 0.5 & 58 \\
\hline Urine storage & $\mathrm{kg} / \mathrm{hh} / \mathrm{y}$ & 1320 & 1.17 & 1.17 & 20.6 & 20.6 & 0 \\
\hline
\end{tabular}

$\mathrm{TP}=$ total phosphorus, av. $\mathrm{P}=$ available Phosphorus, $\mathrm{TN}=$ Total Nitrogen, av. $\mathrm{N}=$ available nitrogen, $\mathrm{OM}=$ organic matter.

Based on the KW and GR production of the average four-person household in Peñalolén, a $0.87 \mathrm{~m}^{3}$ vermicomposter should suffice [78]. For AD, the household organics input requires one unit of a commercially available home-digester, resulting in a $0.5-2 \mathrm{~m}^{2}$ area requirement depending on the model chosen $[79,80]$. The biogas production potential is $88 \mathrm{~m}^{3} / \mathrm{hh} / \mathrm{y}$, representing $9 \%$ of total energy use per household per year in Chile $[67,81]$. Urine is collected using passive diverting urine devices installed on conventional toilets; for hygienic reasons, the urine is stored for half a year before use. For calculations, please refer to Appendix A.

\subsubsection{Municipality Scenarios}

Municipality scenarios are built taking into consideration the totality of Peñalolén households, i.e., 63,294 . In scenario 4, composting of all KW plus GR is considered. In contrast to the household level, at the municipality level, sufficient carbon-rich material is considered to be available from municipal green spaces. In total, 150 tons OSW/d are treated, requiring a composting facility of 14 ha (please refer to Appendix A for calculations).

Scenario 5 considers AD at the municipal level using a sequential batch reactor with internal liquid recirculation [25]. This model is chosen given its lower area demand and suitability to treat OSW. A total of $3110 \mathrm{~m}^{3}$ volume is required to process the OSW of all inhabitants of Peñalolén and $3656 \mathrm{~m}^{2}$ total area, including operations $[25,67]$ (see Appendix A for calculations).

Nutrient recovery from urine through struvite precipitation is considered in scenario 6; urine storage in this case is 60 days and urine is considered to be collected using urine diversion toilets; all technological parameters are taken from a detailed study recently performed [24], with the resulting area requirement being $2720 \mathrm{~m}^{2}$.

The scenarios are shown in Figure 4, and the composition of the final products is shown in Table 3.

Table 3. Amount and composition of the digestate, compos, and struvite that can be produced at the municipal level in Peñalolén per household per year.

\begin{tabular}{lccccccc}
\hline & Unit & Mass & TP & av. P & TN & av. N & OM \\
\hline Digestate & $\mathrm{kg} / \mathrm{hh} / \mathrm{y}$ & 600 & 0.75 & 0.34 & 4.3 & 0.8 & 58 \\
Compost & $\mathrm{kg} / \mathrm{hh} / \mathrm{y}$ & 345 & 0.73 & 0.37 & 2.4 & 0.2 & 120 \\
Struvite & $\mathrm{kg} / \mathrm{hh} / \mathrm{y}$ & 8 & 0.99 & 0.99 & 0.4 & 0.4 & 0 \\
\hline
\end{tabular}

$\mathrm{TP}=$ total phosphorus, av. $\mathrm{P}=$ available phosphorus, $\mathrm{TN}=$ total nitrogen, av. $\mathrm{N}=$ available nitrogen, $\mathrm{OM}=$ organic matter. 

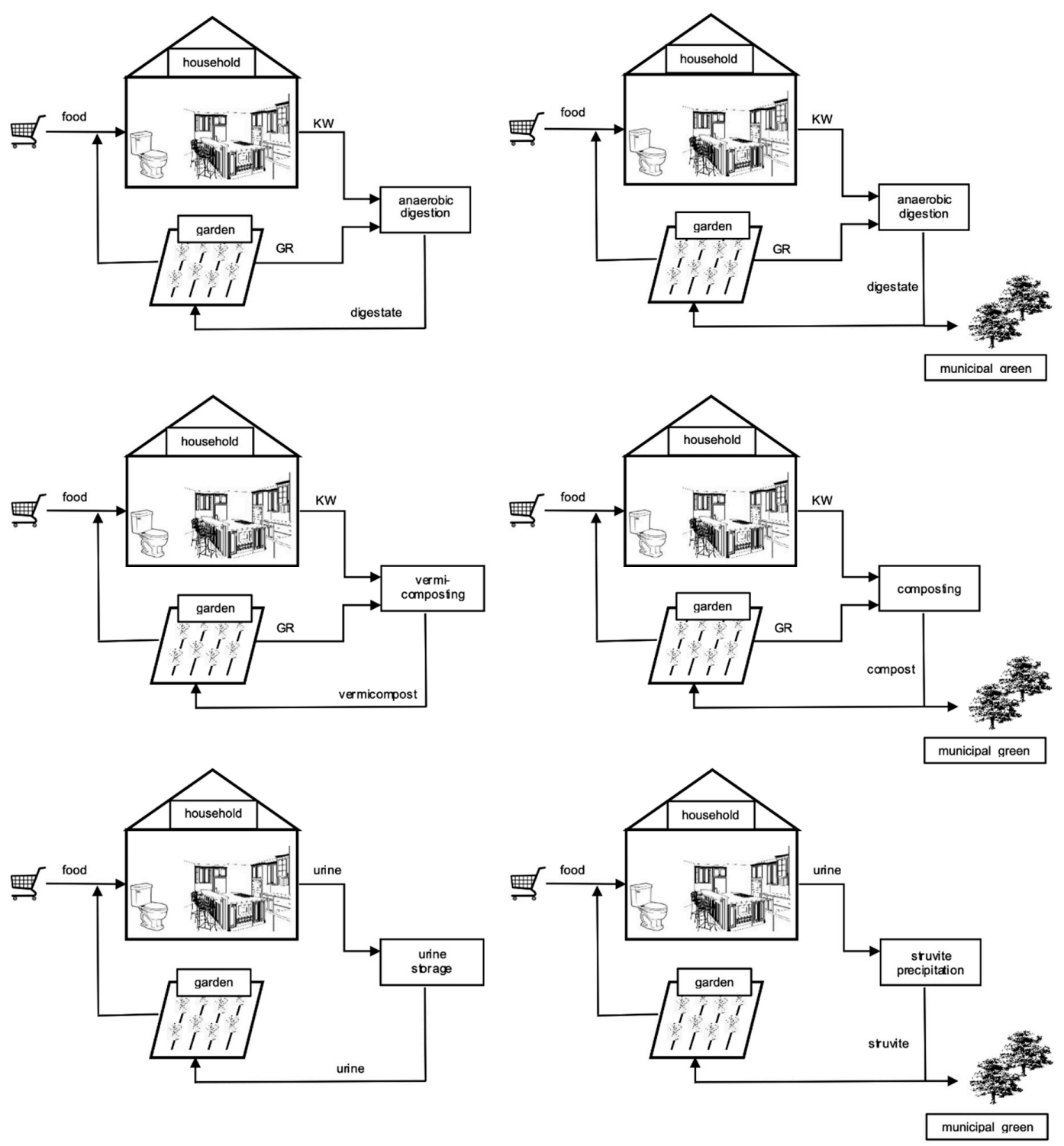

Figure 4. Organic waste management scenarios at the household level (left) and municipal level (right). On the left from upper to lower: Scenario 1, anaerobic digestion; scenario 2, vermicomposting; scenario 3 , urine storage and reuse. On the right from upper to lower: Scenario 4, anaerobic digestion; scenario 5 , composting; scenario 6, struvite precipitation.

\subsection{Scenario Performance}

\subsubsection{Self-Sufficiency Index (SSI)}

Based on the composition of recovered flows, as shown in Table 2, SSI can be calculated. This indicator shows to what extent the nutrient demand of each household is covered by means of recovered flows. Calculated composition of the digestate based on inputs yields an available $\mathrm{N}$ (av. $\mathrm{N}$ ) to $\mathrm{P}$ ratio of 2.3 and a total $\mathrm{N}$ to available $\mathrm{P}$ (av. P) ratio of 12.7. Therefore, it matters significantly whether the SSI is calculated based on total or available $\mathrm{N}$ or $\mathrm{P}$. In the case of total N, under-fertilization takes place in terms of $\mathrm{P}$, and in the case of available $\mathrm{N}$, over-fertilization of $\mathrm{P}$ occurs and due to mineralization over the years, over-fertilization in terms of $\mathrm{N}$ as well. When considering a regime based on available $\mathrm{P}$, a shortage of available $\mathrm{N}$ for the first couple of years results, but a surplus of $\mathrm{N}$ occurs over the years. Table 4 summarizes the previous showing the SSI for each case. Tables 2 and 4 show that urine storage and reuse recovers the most nutrients, while vermicomposting performs better 
with regard to available P recovery from OSW and AD is better for total and available $\mathrm{N}$ recovery from the same flow. All SSIs calculated show that the fertilizer production per household is more than the demand of the household garden, i.e., SSI $<0$. Fink et al. [52] gives an average yield of marketable produce of $77 \mathrm{t} / \mathrm{ha} / \mathrm{y}$. Using this figure in the household scenarios for meeting all nutrient demands, a maximum $74 \mathrm{~kg}$ food/hh/y or $51 \mathrm{~g} / \mathrm{p} / \mathrm{d}$ can be produced for the average garden size, which is one-fifth of the recommended vegetable intake [27].

Table 4. Self-sufficiency index (SSI), resource export index (REI), and waste output index (WOI) of total nitrogen (TN), total phosphorus (TP), and organic matter (OM) for all scenarios (kg waste/kg input).

\begin{tabular}{|c|c|c|c|c|c|c|c|c|c|c|c|c|c|}
\hline & \multicolumn{5}{|c|}{ Self-Sufficiency Index (SSI) } & \multicolumn{5}{|c|}{ Resource Export index (REI) } & \multicolumn{3}{|c|}{$\begin{array}{l}\text { Waste Output Index } \\
\text { (WOI) }\end{array}$} \\
\hline & $\mathrm{TN}$ & av. N & ТP & av. $\mathrm{P}$ & $\mathrm{OM}$ & $\mathrm{TN}$ & $\begin{array}{l}\text { av. } \\
\mathrm{N}\end{array}$ & TP & av. $\mathrm{P}$ & $\mathrm{OM}$ & $\mathrm{TN}$ & TP & $\mathrm{OM}$ \\
\hline $\begin{array}{c}\text { Scenario } 1 . \\
\text { Household anaerobic } \\
\text { digestion }\end{array}$ & -12 & -1.4 & -14 & -5.5 & -8.4 & 7 & 0.4 & 7 & 2 & 4.0 & -0.88 & -0.76 & -0.77 \\
\hline $\begin{array}{l}\text { Scenario 2. } \\
\text { Household } \\
\text { vermicomposting } \\
\text { Scenario } 3 .\end{array}$ & -5.5 & -0.54 & -13 & -6.1 & -11 & 3 & -0.1 & 6 & 3 & 5.3 & -0.94 & -0.76 & -0.74 \\
\hline $\begin{array}{l}\text { Household urine } \\
\text { storage and reuse } \\
\text { Scenario } 4 .\end{array}$ & -63 & -63 & -22 & -22 & 1 & 63 & 62.5 & 12 & 22 & -1.0 & -0.42 & -0.62 & -0.99 \\
\hline $\begin{array}{c}\text { Municipal anaerobic } \\
\text { digestion } \\
\text { Scenario } 5 .\end{array}$ & & & & & & 6.6 & 0.40 & 6.6 & 2.4 & 4 & -0.88 & -0.76 & -0.77 \\
\hline $\begin{array}{l}\text { Municipal } \\
\text { composting }\end{array}$ & & & & & & 3.2 & -0.58 & 6.4 & 2.7 & 12.8 & -0.93 & -0.76 & -0.54 \\
\hline $\begin{array}{c}\text { Scenario } 6 . \\
\text { Municipal struvite }\end{array}$ & & & & & & -0.30 & -0.30 & 9.0 & 9.0 & & -0.99 & -0.68 & -1.00 \\
\hline
\end{tabular}

\subsubsection{Resource Export Index (REI)}

Based on the composition of recovered flows in municipal scenarios, as shown in Table 3, the REI shows to what extent the nutrient supply exceeds the demand at municipal level. The REI resembles the SSI, but in our calculation, the REI considers the expanded system limits that is the demand not only from household gardens, but also from municipality green. The different REI are shown in Table 4 . Keeping in mind that an REI of 0 indicates solely self-sufficiency and a negative REI indicates import rather than export of nutrients, what Table 4 shows us is that AD from KW and GR successfully cover all nutrient requirements from household and municipality, whereas vermicomposting and composting also suffice, except for the available N. Splitting the total demand shows that for available $\mathrm{N}$, composting can cover either $99 \%$ of municipality green or $74 \%$ of household garden demand. In the struvite scenario, $\mathrm{P}$ demand is covered, and a surplus remains but $30 \%$ of total $\mathrm{N}$ demand needs to be imported, and splitting the total demand between gardens and municipality green gives the option for $122 \%$ of garden or $164 \%$ of municipality green demand. In all other scenarios, it is shown that the demand can be more than covered and demonstrates opportunities for exporting nutrients in excess.

\subsubsection{Waste Output Index (WOI)}

The waste output index demonstrates to what extent export of wastes is avoided. Waste is defined as those nutrients that are lost to the landfill, WWTP, or to losses to air, water, or soil during waste treatment. Here, the demand from agricultural areas within the MRS is considered in order to minimize nutrient losses. The WOI of all six scenarios is shown in Table 4. As a WOI of -1 means that resources are exported as waste, the baseline has a WOI of -1 .

Purely looking at the WOI as an indicator, scenario 3 with urine storage scores best with regard to keeping $\mathrm{N}$ and $\mathrm{P}$ within the system. AD scores best in terms of nutrient recovery from OSW. As can be observed, the WOI in Table 4 is in many occasions closer to -1 than to 0 , meaning nutrients are being lost. This is partly due to the fact that each scenario only looks at nutrient recovery from either 
OSW or urine. Given their complementarity, it is worth combining them. When scenarios 1 and 3 are combined, an optimal resource recovery of $70 \%$ for $\mathrm{N}$ and $63 \%$ for $\mathrm{P}$ is reached. Nutrients that are still lost are present in the feces stream and the urine that could not be separated by the urine-diverting toilet $(25 \%)$. For OM, composting gives the best recovery possibilities. Recovery from the urine stream is negligible. The optimal OM recovery is, thus, $46 \%$ in scenario 5 (Table 4 ).

\subsection{Economic Analysis}

Scenarios were analyzed on their economic performance based on the methodology described in Section 2. Cost and benefits of the baseline and proposed technological scenarios can be found in Tables 5 and 6. Since municipalities usually pay per weight of waste disposed, the weight of OSW is thus assumed to determine the current costs and potential for landfill savings (See Table 6). These savings could better apply to the household level where no OSW transport would be necessary, however for the municipal level, even though distances are expected to be shorter, the transport costs are assumed to stay the same as the tariff is based on weight; in reality, this price could be diminished once negotiations are undertaken. In future contracts, the municipality could negotiate lower prices related to decreased MSW resulting in, for example, less pick-up moments.

In the case of struvite there is a need for extra transport as urine is currently only transported through the sewer system. As current contracts for transport of municipal waste are weight based; these costs are calculated in relation to weight as well.

The price for digestate, urine, and struvite are determined based on their nutrient content following a pricing method proposed by the UK Environment Agency [21]. This also requires knowledge on the potassium $(\mathrm{K})$ content of the fertilizers, therefore an approximation is calculated based on average $\mathrm{K}$ loads for kitchen waste and urine as found in the literature [15]. The reason that different prices are considered for household-level and municipal-level digestate is that retail prices differ significantly from those for agriculture. Since inhabitants would otherwise have paid retail prices for fertilizers, those prices were used to calculate their benefits, while at the municipal level, lower prices are used due to the larger quantities.

Table 5. Cost and benefits in USD of current domestic solid organic waste management (landfill) and alternative technologies introduced in the technological scenarios (anaerobic digestion, vermicomposting, and composting).

\begin{tabular}{|c|c|c|c|c|c|c|c|}
\hline & & Unit & Landfill $^{1}$ & $\begin{array}{l}\text { Household } \\
\text { Anaerobic } \\
\text { Digestion }^{2}\end{array}$ & $\begin{array}{c}\text { Household } \\
\text { Vermin- } \\
\text { Composting }\end{array}$ & $\begin{array}{c}\text { Municipal } \\
\text { Composting }\end{array}$ & $\begin{array}{c}\text { Municipal } \\
\text { Anaerobic } \\
\text { Digestion } 5\end{array}$ \\
\hline \multirow{2}{*}{ Costs } & Transport & $\$ / \mathrm{hh} / \mathrm{y}$ & 256 & 0 & 0 & 256 & 256 \\
\hline & fees & $\$ / \mathrm{hh} / \mathrm{y}$ & 103 & 0 & 0 & 0 & 0 \\
\hline \multirow{4}{*}{ Benefits } & Compost & $\$ / \mathrm{hh} / \mathrm{y}$ & 0 & 0 & 0 & 36 & 0 \\
\hline & Vermicompost & $\$ / \mathrm{hh} / \mathrm{y}$ & 0 & 0 & 586 & 0 & 0 \\
\hline & Digestate & $\$ / \mathrm{hh} / \mathrm{y}$ & 0 & 6 & 0 & 0 & 7 \\
\hline & Biogas & $\$ / \mathrm{hh} / \mathrm{y}$ & 0 & 128 & 0 & 0 & 128 \\
\hline \multicolumn{2}{|c|}{ Capital Investment } & $\$ / \mathrm{hh}$ & - & 1.506 & 186 & 120 & 1.237 \\
\hline
\end{tabular}


Table 6. Cost and benefits in USD for resource recovery from urine through urine storage and struvite precipitation.

\begin{tabular}{|c|c|c|c|c|}
\hline & & Unit & $\begin{array}{c}\text { Household } \\
\text { Urine Storage }\end{array}$ & $\begin{array}{c}\text { Municipality } \\
\text { Struvite }^{2}\end{array}$ \\
\hline \multirow{4}{*}{ Costs } & Operation & $\$ / \mathrm{hh} / \mathrm{y}$ & - & 0 \\
\hline & Transport & $\$ / \mathrm{hh} / \mathrm{y}$ & - & 39 \\
\hline & Fees & $\$ / \mathrm{hh} / \mathrm{y}$ & - & - \\
\hline & Total costs & $\$ / \mathrm{hh} / \mathrm{y}$ & - & 39 \\
\hline \multirow{3}{*}{ Benefits } & Stored urine & $\$ / \mathrm{hh} / \mathrm{y}$ & 33 & - \\
\hline & Struvite & $\$ / \mathrm{hh} / \mathrm{y}$ & - & 3 \\
\hline & Total benefits & $\$ / \mathrm{hh} / \mathrm{y}$ & 33 & 3 \\
\hline \multicolumn{2}{|c|}{ Profit } & $\$ / \mathrm{hh} / \mathrm{y}$ & 33 & -36 \\
\hline \multicolumn{2}{|c|}{ Capital Investment } & $\$ / \mathrm{hh}$ & 50 & 1.177 \\
\hline
\end{tabular}

The costs for municipal scenarios are based on projects of similar size found in the literature. For composting, the original facility was designed for 40,000 tons of feedstock per year; this compares well to our treatment need of 58,400 tons of OSW and GR per year [22]. In the case of the AD facility, a sequential batch reactor of $3109 \mathrm{~m}^{3}$ was considered; the source that data were extrapolated from considered a $910 \mathrm{~m}^{3}$ reactor, hence lower real investment could be the case due to economies of scale [25]. Given that struvite applications are still limited at full scale, the struvite installation that is used as a reference handles only $1920 \mathrm{~m}^{3}$ urine per year with a total cost of USD 78,293 [24]; this scale is substantially less than our case of $84,000 \mathrm{~m}^{3} / \mathrm{y}$ and this scale difference may mean that, in reality, the actual costs for a struvite installation in Peñalolén will turn out much lower in time, allowing for its feasibility.

Interesting to note from Table 5 is that vermicompost is more profitable from the household perspective than $\mathrm{AD}$ or compost. When inhabitants would use the vermicompost, they would save (or sell and earn) four times more than they could from digestate plus biogas, due to the high market price of vermicompost and the lower investment capital.

Table 6 shows a summary of the cost and benefit for each scenario of resource recovery from urine. It can be observed that the economic value of the stored urine is higher than that of struvite; this has to do with the pricing method used, which assigns a value to the nutrient content in the product; since $\mathrm{N}$ and $\mathrm{K}$ content is much higher in urine than in struvite, the benefits calculated. Further, the economies of scale are clearly visible when comparing household-level and municipal-level options for OSW. While the municipality level options are more technified, the investment capital that is needed per household is significantly lower than for the simple household vermicomposter. However, the municipality installations do require costs for operation and transport, and especially the transport costs make it that they do not run a profit. The NPV of resource recovery from urine through urine storage is $\$ 171$ USD for household and the payback period is just two years. When we analyze the whole Peñalolen municipality, the NPV reach $\$ 6,835,916$ USD, considering that according to our survey $63 \%$ of the population declare to be willing to reuse their urine.

Finally, Table 7 shows a summary of the cost-benefit analysis carried out for each scenario. We can clearly see that, except for scenario 4, Municipal AD, all other scenarios are worth the investment, showing positive NVPs and very short PP of four years or less. 
Table 7. Summary table for the cost-benefit analysis highlighting the cost savings, benefits, investment, net present value (NPV), and payback period (PP) for each scenario.

\begin{tabular}{ccccc}
\hline \$ & Household AD & $\begin{array}{c}\text { Household } \\
\text { Vermin-Composting }\end{array}$ & $\begin{array}{c}\text { Municipal } \\
\text { Composting }\end{array}$ & Municipal AD \\
\hline CostTUWMS & 359 & 359 & 359 & 359 \\
\hline CostDVRF & 0 & 0 & 270 & 568 \\
\hline BenfDVRF & 135 & 586 & 36 & 135 \\
\hline Investment & 1506 & 186 & 31,647 & 1237 \\
\hline $\mathrm{N}$ & 12,659 & 12,659 & 719 & 31,647 \\
\hline $\begin{array}{c}\text { NPV (per } \\
\text { household) }\end{array}$ & 1809 & 6155 & $\$ 22,746,603$ & -1734 \\
\hline NPV (social) & $\$ 22,896,987$ & $\$ 77,915,255$ & 2 & - \\
\hline PP (years) & 4 & 1 & &
\end{tabular}

Both household scenarios operate at a positive NPV from the perspective of the inhabitant, but also from a social point of view. Indeed, considering that according to our survey $20 \%$ of households are willing to implement such policies, the NPV is over $\$ 22$ and \$77 million USD for the household AD and household vermicomposting policies, respectively.

On the other hand, only the Municipal composting scenario is profitable with an NPV of $\$ 719$ USD per household. Interestingly, since about $50 \%$ of the household would agree to a Municipal composting, the social NPV of this policy would be over \$22 millions USD, very similar to the household AD scenario.

\section{Discussion}

\subsection{Feasibility of Achieving Nutrient Circularity through Decentralized OSW Solutions}

In order to handle their own residues, a municipality in Santiago de Chile could choose between a household on-site approach or a municipality facility.

From a household perspective, (i) disposition to reuse fertilizer, (ii) economic considerations, and (iii) area availability are of interest to define feasibility of nutrient recovery through decentralized solutions. There is potential coming from the almost $60 \%$ of inhabitants that are positively disposed to use urine as a fertilizer. If urine recovery alone is implemented, urine storage alone would already aid to resource recovery with $58 \%$ of $\mathrm{N}$ and $38 \%$ of P. Regarding nutrient recovery from OSW, N recovery rates from vermicomposting are lower than from anaerobic digestion: $6 \%$ of $\mathrm{N}$ and $24 \%$ of $\mathrm{P}$ versus $12 \%$ of $\mathrm{N}$ and $24 \%$ of $\mathrm{P}$, respectively. Still, vermicomposting can already cover the household nutrient demand. Both vermicomposting and $\mathrm{AD}$ deliver profits due to sales or savings of vermicompost, digestate, and biogas. However, for $\mathrm{AD}$, these profits are lower, and the investment costs higher as compared to vermicomposting. Additionally, vermicomposting uses two times less space; this is expected to be available for most housing types in Peñalolén with a garden or balcony. Also, for household $\mathrm{AD}$, no space limitations are foreseen for the smaller version occupying $0.5-1 \mathrm{~m}^{2}$. Urine storage, however, is only realistic for houses with a considerable garden or storage space as it requires six times more space than vermicomposting, higher capital investment, and deliver lower profits.

At the municipal level, from a nutrient recovery perspective, AD shows higher nutrient recovery rates than composting: $12 \%$ of $\mathrm{N}$ and $24 \%$ of $\mathrm{P}$ versus $7 \%$ of $\mathrm{N}$ and $24 \%$ of $\mathrm{P}$, respectively. Adding struvite precipitation to the possibilities for nutrient recovery at the municipal level would significantly increase P recovery: $13 \%$ of $\mathrm{N}$ and $57 \%$ of P recovered considering AD + struvite. Regarding feasibility, three constraints would have to be overcome: (i) Available land area, (ii) initial costs, and (iii) difficulty for obtaining permits. From our analysis it is shown that composting has much larger land requirements than AD but lower investment costs, and both of them would imply savings to the municipality. On the 
other hand, compost is the fertilizer type that people currently use and prefer the most. With respect to struvite, due to high investment capital requirements and not delivering any financial profits, this is less likely to be pursued.

Both vermicomposting at the household level and composting at the municipality level are economically feasible options that would enable enough nutrients to be recovered to meet the household or municipality demand despite the fact that available $\mathrm{N}$ content of those fertilizers is the lowest compared to demand.

Since $76 \%$ of inhabitants are interested in UA, there is potential for them to produce food with their nutrients. If they would use their own garden space, they could produce, on average, one-fifth of their own fruit/vegetable demand using the valorized nutrients from their own OSW. When assuming fertilizers are made available at the municipality level through the AD of OSW, nutrient recovery is optimized, and reuse for household gardens and municipality green areas is exceeded, then nutrients need to be exported to agriculture to allow for closing nutrient cycles. In total, 101 extra hectares could be fertilized outside of the municipality while still providing one-fifth of vegetable consumption of Peñalolén inhabitants.

Further research in terms of feasibility of circular reuse of nutrients at the city level can be undertaken in several areas. First, there is a need to validate, on-site, several crucial factors by means of pilot studies that, for example, allow measuring: Space availability, efficiencies in OSW separation and resulting OSW composition, quality of the final products achieved though household OSW valorization (including toxicity from cross-contamination with other residues), UA practices, productivities and end-product quality, attitudes towards waste handling and consumption of food produced using valorized OSW, the cost structures of the whole process, and the potential economies of scale.

At the city level, it would also be desirable to define urban typologies that allow for mapping; in more detail, the possibilities for the decentralized options exposed is also of interest, particularly area availability, and transport distances are foreseen as a major limitation.

In this same line, studies that allow measuring and comparing the success rates of the programs already in motion is crucial, both within Santiago de Chile and elsewhere. Case comparison with cities already pursuing decentralized collection and reuse can give us a better idea of the true cost of the policy fostered by this research and the maximum benefits achievable not only in terms of nutrients and waste handling, but on its overall attitude towards resources. Indeed, a potential benefit of people taking care of their own residues is to change their consumption habits, which usually are the most difficult to change and also the most effective in a circular economy; this is to REDUCE.

\subsection{On the Social Benefits of Decentralized Valorization of Residual Flows}

Usually, in a project appraisal, when environmental and social impacts are unquantified, the social NPV is underestimated, since, implicitly, the negative externalities are valued at a price of zero, creating biased results. This is the case in the presented analysis, as we performed a cost-benefit analysis using private prices.

Therefore, we would like to stress that many other important benefits of the decentralized valorization of residual flows are beyond the nutrient recovery, as follows. Firstly, the cost of landfilling can only increase through time, as the discontent of the communities that have to deal with them as neighbors is an enormous negative externality. Secondly, the transportation costs of waste can also only increase through time, producing again immense negative externalities such as congestion and air pollution. Thirdly, nutrients need to be brought back to the agricultural sector (and/or urban agriculture) where food consumed in the city is being produced, causing negative impacts as well, particularly resource depletion and indirect energy consumption. This is the worst part because society must pay for getting rid of the nutrients and, later, must pay even more to bring them back to the agricultural system.

In the same way, there are several positive externalities linked to the decentralized valorization of residual flows. Firstly, people become more aware of their own residues production; since environmental 
consciousness is nowadays a key public policy aim in its own, we could argue that this could be the most important benefit of this policy. Secondly, the investment and risk of the waste management task is spreading among the population; this no doubt alleviates the municipal budget burden of the initiative. Thirdly, the monitoring and control of this very important part of the waste management system, the OSW treatment, could be improved as the treatment and disposal is done by the interested party who directly perceives both the costs and benefits of their effort.

Hence, our performed economic analysis still underestimates the economic and social benefits of this policy, concentrating on the savings of the direct private costs. Follow-up research is being undertaken to approach this limitation.

\section{Conclusions}

OSW make up $48 \%$ of MSW in Chile. With this case study, performed in the Peñalolén municipality within Santiago de Chile, we have assessed the potential and cost-effectiveness of closing nutrient cycles using decentralized valorization techniques.

At the household level, our findings show vermicomposting is the most interesting technology for OSW valorization considering self-sufficiency in nutrients, land requirement, and economic investment and profits. Household vermicomposting can meet household and municipal nutrient demand, even allowing for nutrient export in the case of $\mathrm{P}$, even though its nutrient recovery potential reaches $6 \%$ of $\mathrm{N}$ and $24 \%$ of $\mathrm{P}$ considering total food intake. Important cost savings and economic benefits as compared to the current disposal system are also the case; in particular, the NPV of vermicomposting is $\$ 6155$ USD per household and over $\$ 77$ millions USD for the social NPV.

At the municipal level, land requirements and nutrient recovery make $\mathrm{AD}$ a more attractive option; in particular, AD of KW and GR can meet $140 \%$ of nutrient demand of gardens and municipal green. This nutrient demand relates to a nutrient recovery potential of $12 \%$ of $\mathrm{N}$ and $24 \%$ of $\mathrm{P}$ that enters a household in the form of food. However, considering investment and its return, composting turns out to be the most promising option at the municipal level. Nevertheless, interestingly, AD at the household level outweights the economic benefits of municipal composting, being both profitable from a household and social perspective.

Resource recovery from urine is not an attractive option for either municipality or inhabitants due to space requirements when pursued at the household level and costs when reaching for the municipal alternative. This implies missing out on a chance to recover up to $58 \%$ of $\mathrm{N}$ and $38 \%$ of $\mathrm{P}$ entering the household.

Author Contributions: Conceptualization, C.P.-P.; methodology, C.P.-P, K.K.-R., M.J.V.; software, J.d.K.; formal analysis, J.d.K., C.P.-P, M.J.V., K.K.-R.; investigation, J.d.K., C.P.-P.; resources, CP P. P.; data curation, J.d.K.; writing-original draft preparation, J de Kraker, C.P.-P.; writing-review and editing, J de Kraker, C.P.-P., M.J.V., K.K.-R.; visualization, J.d.K., C.P.-P.; supervision, C.P.-P., K.K.-R.; project administration, C.P.-P., K.K.-R.; funding acquisition, K.K.-R.

Funding: This research received no external funding.

Acknowledgments: The authors would like to thank Municipalidad de Peñalolen and Universidad Adolfo Ibáñez for hosting the execution of this research at EcoParque Peñalolén-UAI during the second semester of 2017.

Conflicts of Interest: The authors declare no conflict of interest.

\section{List of Abbreviations}

$\begin{array}{ll}\text { AD } & \text { Anaerobic Digestion } \\ \text { Av N } & \text { Available N } \\ \text { Av P } & \text { Available P } \\ \text { C } & \text { Carbon } \\ \text { CF } & \text { Cash Flow } \\ \text { CLP } & \text { Chilean Peso } \\ \text { COD } & \text { Chemical Oxygen Demand } \\ \text { D } & \text { Demand }\end{array}$


DFI Daily Food Intake

DVRF Decentralized Valorization of Residual Flows

$\mathrm{E}_{\mathrm{r}} \quad$ Exportable resources

EUR Euro

GR Garden Residues

Ip Internal Production

K Potassium

KW Kitchen Waste

MFA Material Flow Analysis

MRS Metropolitan Region of Santiago

$\mathrm{M}_{\text {struvite }} \quad$ Struvite Mass

MSW Municipal Solid Waste

$\mathrm{MW}_{\text {MAP }} \quad$ Molecular Weight of Struvite

$\mathrm{N} \quad$ Nitrogen

NPV Net Present Value

OM Organic Matter

OSW Organic Solid Waste

P Phosphorus

PP Payback Period

$\mathrm{Q}_{\mathrm{u}} \quad$ Urine Flow

R Recycled

REI Resource Export Index

SEG Socio-Economic Group

SSI Self-Sufficiency Index

$\mathrm{T}_{\mathrm{i}} \quad$ Total Input

TUWMS Traditional Urban Waste Management System

UA Urban Agriculture

UHA Urban Harvest Approach

USD United States Dollar

VS Volatile Solids

$\mathrm{W}_{\mathrm{E}} \quad$ Waste exported

WOI Waste Output Index

WWTP Waste Water Treatment Plant

$\Delta \mathrm{C}_{\mathrm{PO} 4-\mathrm{P}} \quad$ Difference in Phosphorus concentration between the influent and the effluent

\section{Appendix A Calculations}

NOTE: Literature sources and references for the assumptions shown are explained in detail within the main text of the article.

\section{Vermicomposting}

Size of Vermicomposter

Assumptions:

- $\quad$ Kitchen waste and garden residue production is $719 \mathrm{~kg}$ per household per year

- A worm bin measuring $1 \mathrm{ft}^{3}\left(=1 / 35 \mathrm{~m}^{3}\right)$ can process 1 pound $(=0.454 \mathrm{~kg})$ of kitchen waste per week (Angima et al., 2011)

- $\quad$ length vermicomposter is $1.5 \mathrm{~m}$ (common balcony depth)

- height vermicomposter is $0.90 \mathrm{~m}$ (common counter and balcony rail height)

OSW $=719 / 52=13.8 \mathrm{~kg} / \mathrm{hh} /$ week

Volume vermicomposter $=13.8 / 0.454=30.5 \mathrm{ft}^{3}=0.87 \mathrm{~m}^{3}$

Depth vermicomposter $=$ volume/length/height $=0.87 \mathrm{~m}^{3} / 1.5 \mathrm{~m} / 0.9 \mathrm{~m}=0.64 \mathrm{~m}$

Ground area vermicomposter $=$ length $\times$ depth $=0.64 \mathrm{~m} \times 1.5 \mathrm{~m}=1.0 \mathrm{~m}^{2}$ 
Volumetric Efficiency

Assumptions:

- $50 \%$ volume reduction is achieved after the treatment

$\mathrm{V}_{\text {out }}=\mathrm{V}_{\text {in }} \times 0.50$

Nutrient Efficiency

Assumptions:

- $\quad 49 \%$ of $\mathrm{N}$ is left after the process, of this $24 \%$ is in its mineralized available form

- $\quad 97 \%$ of $\mathrm{P}$ remains in the final product, of this $50 \%$ is in its mineralized available form

$\mathrm{TN}_{\text {out }}=\mathrm{TN}_{\text {in }} \times 0.49$

Available $\mathrm{N}_{\text {out }}=\mathrm{TN}_{\text {out }} \times 0.24$

$\mathrm{TP}_{\text {out }}=\mathrm{TP}_{\text {in }} \times 0.97$

Available $\mathrm{P}_{\text {out }}=\mathrm{TP}_{\text {out }} \times 0.50$

Composting

Amount of Carbon Rich Material to Add

To calculate the amount of carbon rich residue to add, the following equation is used:

$$
Q_{2}=\frac{Q_{1} \times N_{1} \times\left(R-\frac{C_{1}}{N_{1}}\right) \times\left(100-M_{1}\right)}{N_{2} \times\left(\frac{C_{2}}{N_{2}}-R\right) \times\left(100-M_{2}\right)}
$$

where $\mathrm{R}$ is $\mathrm{C} / \mathrm{N}$ ratio of the compost mixture, $\mathrm{Q}_{1}$ is the mass of $\mathrm{KW}$ ("as is", or "wet weight") $\mathrm{C}_{1} / \mathrm{N}_{1}=$ is Carbon to Nitrogen ratio of $K W, M_{1}=$ moisture content (\%) of $K W . Q_{2}$ is the mass of GR ("as is", or "wet weight") $C_{2} / N_{2}=$ is Carbon to Nitrogen ratio of GR, $\mathrm{M}_{2}=$ moisture content ( $\%$ ) of GR.

- Assumptions used regarding waste composition for the equation are:

- $\quad$ Target $\mathrm{C} / \mathrm{N}$ ratio of compost mixture $\mathrm{R}$ is 30

- $\quad$ Kitchen Waste: Moisture $=69 \% ; \mathrm{N} \%=3 \% ; \mathrm{C} / \mathrm{N}=15$

- Garden Residues: Moisture $=15 \% ; \mathrm{N} \%=3.5 \% ; \mathrm{C} / \mathrm{N}=35$

- $\quad$ Amount of $\mathrm{KR}=721 \mathrm{~kg} / \mathrm{hh} / \mathrm{y}$ or $125 \mathrm{ton} / \mathrm{yr}$ for the whole municipality

- Extra carbon rich material to add daily is 35 tons of GR

Area $=544 \mathrm{~m} \times 6 \mathrm{~m} \times 30 \mathrm{~m}=10$ ha for composting

Total area $=10 \times 200 \%=20$ ha including storage and operation

Size of Composting Facility

- Assumptions:

- $\quad$ KR production in Peñalolen is 125 ton/d

- $\quad$ Bulk density $\mathrm{KR}=350 \mathrm{~kg} / \mathrm{m}^{3}$

- $\quad$ Extra GR to add is $35 \mathrm{ton} / \mathrm{d}$

- Bulk density GR $=250 \mathrm{~kg} / \mathrm{m}^{3}$

- Retention time for compost maturation: 6 months

- Height of the compost pile is $1.2 \mathrm{~m}$

- $\quad$ Extra area needed for composting facilities: $200 \%$

Total area composting $\left(\mathrm{m}^{2}\right)=\left(\left(\left(125 \mathrm{ton} / \mathrm{d} \times 1000 \mathrm{~kg} /\right.\right.\right.$ ton $\left.\times 565 \mathrm{~kg} / \mathrm{m}^{3}\right)+(35 \mathrm{ton} / \mathrm{d} \times 1000 \mathrm{~kg} / \mathrm{ton} \times 250$ $\left.\left.\left.\mathrm{kg} / \mathrm{m}^{3}\right)\right) / 1.2 \mathrm{~m}\right) \times 6$ months $\times 30 \mathrm{~d} /$ month $\times 200 \%$

\section{Volumetric Efficiency}

Volume reduction during the treatment is $50 \%$

$\mathrm{V}_{\text {out }}=\mathrm{V}_{\text {in }} \times 0.50$ 
Nutrient Efficiency

$\mathrm{TN}_{\text {out }}=\mathrm{TN}_{\text {in }} \times 0.55$

Available $\mathrm{N}_{\text {out }}=\mathrm{TN}_{\text {out }} \times 0.10$

$\mathrm{TP}_{\text {out }}=\mathrm{TP}_{\text {in }} \times 0.97$

Available $\mathrm{P}_{\text {out }}=\mathrm{TP}_{\text {out }} \times 0.50$

$\mathrm{OM}_{\text {out }}=\mathrm{OM}_{\text {in }} \times 0.67$

Municipal Biodigester

Size of Biodigester

Assumptions:

- A sequential batch biodigester of $910 \mathrm{~m}^{3}$ can process 36.5 ton OSW/day and needs a floor area of $1070 \mathrm{~m}^{2}$ including operations [25]

- Domestic OSW production in Peñalolén is 125 ton/day

- OSW density is $350 \mathrm{Kg} / \mathrm{m}^{3}$

- Hidraulic Retention time is 8.7 days

- $\quad$ Digester height: $2 \mathrm{~m}$

- Total area needed including operations is $235 \%$ of reactor area

Volume biodigester $=125 \mathrm{ton} / \mathrm{d} \times 1000 \mathrm{~kg} / \mathrm{ton} \times 350 \mathrm{~kg} / \mathrm{m}^{3} \times 8.7 \mathrm{~d}=3110 \mathrm{~m}^{3}$

Area biodigester $=3110 \mathrm{~m}^{3} / 2 \mathrm{~m} \times 235 \%=3656 \mathrm{~m}^{2}$

\section{Biogas Production}

\section{Assumptions:}

- Kitchen waste and garden residue production is $719 \mathrm{~kg}$ per household per year

- Average biogas production from domestic residues is $0.55 \mathrm{~m}^{3} / \mathrm{kg}$ VS [67]

- $\quad$ OSW contains $0.37 \mathrm{~kg}$ VS per $\mathrm{kg}$ OSW [67]

Biogas production $=719 \mathrm{Kg} / \mathrm{yr} \times 0.37 \mathrm{Kg} \mathrm{VS} / \mathrm{Kg} \times 0.55 \mathrm{~m} 3$ biogas $/ \mathrm{Kg} \mathrm{VS}=146 \mathrm{~m}^{3} / \mathrm{hh} / \mathrm{y}$

\section{Nutrient Efficiency}

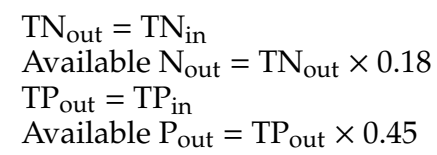

\section{Urine Storage}

\section{Storage Volume}

\section{Assumptions:}

- Urine production is $4.8 \mathrm{~L}$ per household per day

- $75 \%$ of urine produced can be captured for storage

- Urine needs to be stored for half a year

- Storage takes place in $60 \mathrm{~L}$ tanks

- Tanks have a diameter of $40 \mathrm{~cm}$ [87]

- Tanks have a height of $60 \mathrm{~cm} \mathrm{[87]}$

Urine volume to be stored $=4.8 \mathrm{~L} \times 0.75 \times(365 / 2)=660 \mathrm{~L} \mathrm{~s}$

Number of tanks needed $=660 \mathrm{~L} / 60 \mathrm{~L} / \operatorname{tank}=11$ tanks

Area required tanks $=\left(11\right.$ tanks $\left.\times 0.2^{2} \times 3.1416\right)=1.38 \mathrm{~m}^{2}$ per household

Effective area needed $=$ length $\times$ width $=0.4 \mathrm{~m} \times 11$ tanks $\times 0.4 \mathrm{~m}=1.8 \mathrm{~m}^{2}$

Nutrient Efficiency

$\mathrm{TN}_{\text {out }}=\mathrm{TN}_{\text {in }}$

Available $\mathrm{N}_{\text {out }}=\mathrm{TN}_{\text {out }}$

$\mathrm{TP}_{\text {out }}=\mathrm{TP}_{\text {in }}$

Available $\mathrm{P}_{\text {out }}=\mathrm{TP}_{\text {out }}$ 
Struvite

\section{Struvite Production}

Assumptions:

- Urine production is $4.8 \mathrm{~L}$ per household per day, containing $4.28 \mathrm{~g}$ phosphorus per household per day

- Molecular weight of $P$ is $31 \mathrm{~g} / \mathrm{mol}$

- $75 \%$ of urine produced can be captured for struvite production

- $85 \%$ of phosphorus in urine can be recovered

- Molecular weight of struvite is $245 \mathrm{~g} / \mathrm{mol}$

- The theoretical struvite mass can be calculated with the formula:

$$
M_{\text {struvite }}=Q * \triangle C_{P O 4-P} * M W_{M A P}
$$

$\mathrm{M}_{\text {struvite }} \quad$ struvite mass $[\mathrm{kg} / \mathrm{d}]$

$\mathrm{Q}$ urine inflow [L/d]

$\Delta \mathrm{C}_{\mathrm{PO} 4-\mathrm{P}} \quad$ difference in phosphorus concentration between the influent and the effluent $[\mathrm{mol} / \mathrm{L}]$

MW $W_{\text {MAP }}$ molecular weight of struvite $[\mathrm{kg} / \mathrm{mol}]$

$\mathrm{C}_{\mathrm{PO} 4-\mathrm{P}, \text { in }}=4.28 \mathrm{~g} \mathrm{P} / 31 \mathrm{~g} / \mathrm{mol} / 4.8 \mathrm{~L} \times 0.75=0.215 \mathrm{~mol} \mathrm{P} / \mathrm{L}$ urine

Struvite production $=4.8 \mathrm{~L} \times(0.85 \times 0.215) \times 0.245 \times 365=7.8 \mathrm{~kg} / \mathrm{hh} / \mathrm{y}$

Area Requirement

Assumptions:

- Urine production is $4.8 \mathrm{~L}$ per household per day

- Average household size in Peñalolén is 4 people

- Population of Peñalolén is 253,175 people

- $75 \%$ of urine produced can be captured for struvite production

- $\quad 0,2 \mathrm{~m} 2 / \mathrm{m} 3$ struvite

- $60 \mathrm{~d}$ storage time

Urine input $=4.8 / 4 \times 253,175 / 1000 \times 365=83,168 \mathrm{~m}^{3} / \mathrm{y}$

Area required $=\left(83,168 \mathrm{~m}^{3} / \mathrm{y} / 365 \mathrm{~d} / \mathrm{y}\right) \times 0.2 \mathrm{~m}^{2} / \mathrm{m}^{3} \times 60 \mathrm{~d} / 10000 \mathrm{ha} / \mathrm{m}^{2}=0.272 \mathrm{ha}$

\section{References}

1. Dijst, M.; Worrell, E.; Böcker, L.; Brunner, P.; Davoudi, S.; Geertman, S.; Harmsen, R.; Helbich, M.; Holtslag, A.A.M.; Kwan, M.; et al. Exploring urban metabolism—towards an interdisciplinary perspective. Resour. Conserv. Recycl. 2018, 132, 190-203.

2. Kennedy, C.; Pincetl, S.; Bunje, P. The study of urban metabolism and its applications to urban planning and design. Environ. Pollut. 2011, 159, 1965-1973.

3. Scholz, R.W.; Ulrich, A.E.; Eilittä, M.; Roy, A. Sustainable use of phosphorus: A finite resource. Sci. Total Environ. 2013, 461, 799-803. [CrossRef] [PubMed]

4. Vaneeckhaute, C.; Meers, E.; Michels, E.; Buysse, J.; Tack, F.M.G. Ecological and economic benefits of the application of bio-based mineral fertilizers in modern agriculture. Biomass Bioenergy 2013, 49, 239-248. [CrossRef]

5. Zeeman, G.; Kujawa-Roeleveld, K. Resource recovery from source separated domestic waste (water) streams; full scale results. Water Sci. Technol. 2011, 64, 1987-1992. [PubMed]

6. de Haan, J.J.; van Geel, W.C.A. Adviesbasis Voor de Bemesting van Akkerbouwgewassen: Samenstelling Commissie. 2013. Available online: https://www.researchgate.net/publication/283398521_Adviesbasis_voor_ de_bemesting_van_akkerbouwgewassen (accessed on 1 November 2019).

7. Wielemaker, R.C.; Weijma, J.; Zeeman, G. Harvest to harvest: Recovering nutrients with New Sanitation systems for reuse in Urban Agriculture. Resour. Conserv. Recycl. 2018, 128, 426-437. [CrossRef]

8. MMA. Política Nacional de Economía Circular. Available online: https://mma.gob.cl/economia-circular/ (accessed on 14 August 2019).

9. CONAMA RM. Primer Reporte Sobre Manejo de Residuos Sólidos en Chile; CONAMA RM: Santiago, Chile, 2010.

10. MMA. 2015 ESTRATEGIA REGIONAL DE RESIDUOS SÓLIDOS REGIÓN METROPOLITANA DE SANTIAGO 2017-2021. Available online: https://mma.gob.cl/wp-content/uploads/2018/03/PUBLICEstrategia-Reg-Residuos-Solidos-Digital.pdf (accessed on 3 October 2017). 
11. SUBDERE. 2017, Gobierno Regional Metropolitano de Santiago. Available online: http://www. subdere.cl/división-administrativa-de-chile/gobierno-regional-metropolitano-de-santiago (accessed on 14 December 2017).

12. MMA. Gestión y Valorización de Residuos Sólidos en la Región Metropolitana; MMA: Santiago de Chile, Chile, 2012.

13. Baurier Manuel. Aguas Andinas: de plantas de tratamiento de aguas servidas a biofactorías. Seminario Regional de Bioeconomía en America Latina y el Caribe, 2018. Available online: http://conferencias.cepal. org/bioeconomia_AL/Miercoles\%2024/Pdf/Manuel\%20Baurier.pdf (accessed on 15 August 2019).

14. Hernández, F. Municipalidad de Peñalolén. Environmental Office, Personal Interview: Santiago de Chile, Chile, 2017.

15. Kujawa-Roeleveld, K.; Zeeman, G. Anaerobic Treatment in Decentralised and Source-Separation-Based Sanitation Concepts. Rev. Environ. Sci. Bio/Technol. 2006, 5, 115-139. [CrossRef]

16. AIM Chile, 2008. Grupos Socioeconómicos, Asociación Chilena de Empresas de Investigación de Mercados. Santiago de Chile. Available online: http://https://documentop.com/grupos-socioeconomicos-aim-chile_ 5a0c3b291723dd06d9562903.html (accessed on 15 September 2017).

17. PLADECO. Diagnóstico Comunal Pladeco 2013-2016 Ilustre Municipalidad de Peñalolén; PLADECO: Peñalolén, Chile, 2015.

18. Hendriks, C.; Obernosterer, R.; Müller, D.; Kytzia, S.; Baccini, P.; Brunner, P.H. Material flow analysis: a tool to support environmental policy decision making. Case-studies on the city of Vienna and the Swiss lowlands. Local Environ. 2000, 5, 311-328.

19. Agudelo-Vera, C.M.; Mels, A.; Keesman, K.; Rijnaarts, H. The Urban Harvest Approach as an Aid for Sustainable Urban Resource Planning. J. Ind. Ecol. 2012, 16, 839-850. [CrossRef]

20. Atkinson, G.; Braathen, N.A.; Mourato, S.; Groom, B. Cost Benefits Analysis and the Environment: Further Developments and Policy Use; Organisation for Economic Co-operation and Development: Paris, France, 2018.

21. WRAP. Anaerobic Digestate-Partial Financial Impact Assessment of the Introduction of a Quality Protocol for the Production and Use of Anaerobic Digestate; WRAP: Banbury, UK, 2009.

22. van Haaren, R. Large Scale Aerobic Composting of Source Separated Organic Wastes: A Comparative Study of Environmental Impacts, Costs, and Contextual Effects; Columbia University: New York, NY, USA, 2009.

23. Hebda, C.; Gaustad, G.; Williamson, A.; Trabold, T. Determining economically optimal household organic material management pathways. Resour. Conserv. Recycl. 2016, 108, 88-96. [CrossRef]

24. Ishii, S.K.; Boyer, T.H. Life cycle comparison of centralized wastewater treatment and urine source separation with struvite precipitation: Focus on urine nutrient management. Water Res. 2015, 79, 88-103. [CrossRef] [PubMed]

25. Pabón-Pereira, C.P.; López, L. Informe de prefactibilidad para la valorización de residuos orgánicos en la Comuna de Independencia en la Región Metropolitana de Santiago de Chile. 2016. Available online: http://www.minenergia.cl/autoconsumo/wp-content/uploads/2018/06/Informe-Final-Estudio-WTERM-2018.pdf (accessed on 1 November 2019).

26. Muñoz, O.; Bastias, J.M.; Araya, M.; Morales, A.; Orellana, C.; Rebolledo, R.; Velez, D. Estimation of the dietary intake of cadmium, lead, mercury, and arsenic by the population of Santiago (Chile) using a Total Diet Study. Food Chem. Toxicol. 2005, 43, 1647-1655. [CrossRef] [PubMed]

27. Voedingscentrum. Groente en Fruit. Available online: https:/www.voedingscentrum.nl/nl/gezondeten-met-de-schijf-van-vijf/hoeveel-en-wat-kan-ik-per-dag-eten-/groente-en-fruit.aspx (accessed on 17 November 2016).

28. INE. Número DE Jefes DE Hogar Y DE Otros Miembros Del Hogar Por Relación DE Parentesco Con El Jefe DE Hogar Según Division Politico Administrativa Area Urbana-Rural Sexo Y Grupos DE Edad Del Jefe DE Hogar. Santiago de Chile. Available online: http://www.ine.cl/cd2002/index.php (accessed on 3 October 2017).

29. USDA. National Nutrient Database for Standard Reference Release 28, $2016 . \quad$ Available online: https:/ndb.nal.usda.gov/ndb/search/list?fgcd=\&manu=\&lfacet=\&count=\&max=\&sort=\&qlookup= $\&$ offset $=\&$ format $=$ Abridged $\&$ new $=\&$ measureby $=\& d s=$ Standard + Reference $\&$ order $=($ accessed on 30 November 2016).

30. FAO. Food Energy - Methods of Analysis and Conversion Factors; FAO: Rome, Italy, 2003.

31. Milton, K.; Dintzis, F.R. Nitrogen-to-Protein Conversion Factors for Tropical Plant Samples. Biotropica 1981, 13, 177. [CrossRef] 
32. Bouallagui, H.; Touhami, Y.; Ben Cheikh, R.; Hamdi, M. Bioreactor performance in anaerobic digestion of fruit and vegetable wastes. Process. Biochem. 2005, 40, 989-995. [CrossRef]

33. Cavinato, C.; Fatone, F.; Bolzonella, D.; Pavan, P. Thermophilic anaerobic co-digestion of cattle manure with agro-wastes and energy crops: Comparison of pilot and full scale experiences. Bioresour. Technol. 2010, 101, 545-550. [CrossRef]

34. Cho, J.K.; Park, S.C.; Chang, H.N. Biochemical methane potential and solid state anaerobic digestion of Korean food wastes. Bioresour. Technol. 1995, 52, 245-253. [CrossRef]

35. Jiang, Y.; Heaven, S.; Banks, C. Strategies for stable anaerobic digestion of vegetable waste. Renew. Energy 2012, 44, 206-214. [CrossRef]

36. Kabouris, J.C.; Tezel, U.; Pavlostathis, S.G.; Engelmann, M.; Todd, A.C.; Gillette, R.A. The anaerobic biodegradability of municipal sludge and fat, oil, and grease at mesophilic conditions. Water Environ. Res. 2008, 80, 212-221. [CrossRef]

37. Kaparaju, P.; Rintala, J. Anaerobic co-digestion of potato tuber and its industrial by-products with pig manure. Resour. Conserv. Recycl. 2005, 43, 175-188. [CrossRef]

38. Mshandete, A.; Kivaisi, A.; Rubindamayugi, M.; Mattiasson, B. Anaerobic batch co-digestion of sisal pulp and fish wastes. Bioresour. Technol. 2004, 95, 19-24. [CrossRef]

39. Saddoud, A.; Hassaïri, I.; Sayadi, S. Anaerobic membrane reactor with phase separation for the treatment of cheese whey. Bioresour. Technol. 2007, 98, 2102-2108. [CrossRef] [PubMed]

40. Steffen, R.; Szolar, O.; Braun, R. Feedstocks for Anaerobic Digestion. Available online: https://pdfs. semanticscholar.org/293e/a2a9a8d8315548b8d749f60e4b28378d9dfa.pdf (accessed on 1 November 2019).

41. Veeken, A.; Hamelers, B. Effect of temperature on hydrolysis rates of selected biowaste components. Bioresour. Technol. 1999, 69, 249-254. [CrossRef]

42. Universidad Adolfo Ibáñez. EcoParque Peñalolén-UAI. Santiago de Chile. 2018. Available online: https://ingenieria.uai.cl/ecoparque (accessed on 16 November 2018).

43. Magid, J.; Eilersen, A.; Wrisberg, S.; Henze, M. Possibilities and barriers for recirculation of nutrients and organic matter from urban to rural areas: A technical theoretical framework applied to the medium-sized town Hillerød, Denmark. Ecol. Eng. 2006, 28, 44-54. [CrossRef]

44. Baky, A.; Eriksson, O. Systems Analysis of Organic Waste Management in Denmark; Danish Environmental Protection Agency: Copenhagen, Denmark, 2003.

45. Banks, C.J.; Chesshire, M.; Heaven, S.; Arnold, R. Anaerobic digestion of source-segregated domestic food waste: Performance assessment by mass and energy balance. Bioresour. Technol. 2011, 102, 612-620. [CrossRef]

46. CONAMA RM. Estudio de Caracterización de Residuos Domiciliarios en La Región Metropolitana; CONAMA RM: Valparaiso, Chile, 2006.

47. El-Mashad, H.M.; Zhang, R. Biogas production from co-digestion of dairy manure and food waste. Bioresour. Technol. 2010, 101, 4021-4028. [CrossRef]

48. Sundberg, C.; Franke-Whittle, I.H.; Kauppi, S.; Yu, D.; Romantschuk, M.; Insam, H.; Jönsson, H. Characterisation of source-separated household waste intended for composting. Bioresour. Technol. 2011, 102, 2859-2867. [CrossRef]

49. Zhang, R.; Elmashad, H.; Hartman, K.; Wang, F.; Liu, G.; Choate, C.; Gamble, P. Characterization of food waste as feedstock for anaerobic digestion. Bioresour. Technol. 2007, 98, 929-935. [CrossRef]

50. Boldrin, A.; Christensen, T.H. Seasonal generation and composition of garden waste in Aarhus (Denmark). Waste Manag. 2010, 30, 551-557. [CrossRef]

51. Conama, R.M. Sistemas de Reciclaje, Estudio de Casos en la Región Metropolitana; CONAMA RM: Santiago, Chile, 2005.

52. Fink, M.; Feller, C.; Scharpf, H.-C.; Weier, U.; Maync, A.; Ziegler, J.; Paschold, P.-J.; Strohmeyer, K. Nitrogen, phosphorus, potassium and magnesium contents of field vegetables-Recent data for fertiliser recommendations and nutrient balances. J. Plant Nutr. Soil Sci. 1999, 162, 71-73. [CrossRef]

53. Rose, C.; Parker, A.; Jefferson, B.; Cartmell, E. The Characterization of Feces and Urine: A Review of the Literature to Inform Advanced Treatment Technology. Crit. Rev. Environ. Sci. Technol. 2015, 45, 1827-1879. [CrossRef]

54. Observatorio de Ciudades. Formulación Sello de Eficiencia Hidrica en el Paisaje; DGA: Santiago, Chile, 2009. 
55. Beegle, D.B.; Durst, P.T. Managing Phosphorus for Crop Production. Penn State University, 2002. Available online: https://extension.psu.edu/programs/nutrient-management/educational/soil-fertility/ managing-phosphorus-for-crop-production/extension_publication_file (accessed on 15 March 2017).

56. Cornell Waste Management Institute. Compost Chemistry. 1996. Available online: http://compost.css.cornell. edu/chemistry.html (accessed on 15 March 2017).

57. Andersen, J.K.; Boldrin, A.; Christensen, T.H.; Scheutz, C. Mass balances and life-cycle inventory for a garden waste windrow composting plant (Aarhus, Denmark). Waste Manag. Res. 2010, 28, 1010-1020. [CrossRef] [PubMed]

58. Benito, M.; Masaguer, A.; Moliner, A.; Arrigo, N.; Palma, R.M. Chemical and microbiological parameters for the characterisation of the stability and maturity of pruning waste compost. Biol. Fertil. Soils 2003, 37, 184-189.

59. Eklind, Y.; Kirchmann, H. Composting and storage of organic household waste with different litter amendments. II: Nitrogen turnover and losses. Bioresour. Technol. 2000, 74, 125-133. [CrossRef]

60. Fornes, F.; Mendoza-Hernández, D.; García-De-La-Fuente, R.; Abad, M.; Belda, R.M. Composting versus vermicomposting: A comparative study of organic matter evolution through straight and combined processes. Bioresour. Technol. 2012, 118, 296-305. [CrossRef] [PubMed]

61. Michel, F.C.; Reddy, C.A.; Forney, L.J. Yard Waste Composting: Studies Using Different Mixes of Leaves and Grass in a Laboratory Scale System. Compos. Sci. Util. 1993, 1, 85-96. [CrossRef]

62. Sierra, J.; Desfontaines, L.; Faverial, J.; Loranger-Merciris, G.; Boval, M. Composting and vermicomposting of cattle manure and green wastes under tropical conditions: Carbon and nutrient balances and end-product quality. Soil Res. 2013, 51, 142-151. [CrossRef]

63. Frederickson, J.; Butt, K.R.; Morris, R.M.; Daniel, C. Combining vermiculture with traditional green waste composting systems. Soil Boil. Biochem. 1997, 29, 725-730. [CrossRef]

64. Rijksoverheid. Mestbeleid 2014-2017 Tabellen; Rijksoverheid: The Hague, The Netherlands, 2014.

65. RÖBEN, Eva. Manual de compostaje para municipios. Available online: http://www.resol.com.br/Cartilha7/ ManualCompostajeparaMunicipios.pdf (accessed on 1 November 2019).

66. Othman, N. Vermicomposting of food waste. Int. J. Integr. Eng. 2012, 4, 39-48.

67. Kothari, R.; Pandey, A.; Kumar, S.; Tyagi, V.; Tyagi, S. Different aspects of dry anaerobic digestion for bio-energy: An overview. Renew. Sustain. Energy Rev. 2014, 39, 174-195. [CrossRef]

68. Pabón-Pereira, C.; De Vries, J.; Slingerland, M.; Zeeman, G.; Van Lier, J. Impact of crop-manure ratios on energy production and fertilizing characteristics of liquid and solid digestate during codigestion. Environ. Technol. 2014, 35, 2427-2434. [CrossRef]

69. Jönsson, H. Urine separating sewage systems-environmental effects and resource usage. Water Sci. Technol. 2002, 46, 333-340. [CrossRef] [PubMed]

70. Lind, B.-B.; Bán, Z.; Bydén, S. Nutrient recovery from human urine by struvite crystallization with ammonia adsorption on zeolite and wollastonite. Bioresour. Technol. 2000, 73, 169-174. [CrossRef]

71. Ganrot, Z.; Dave, G.; Nilsson, E. Recovery of N and P from human urine by freezing, struvite precipitation and adsorption to zeolite and active carbon. Bioresour. Technol. 2007, 98, 3112-3121. [CrossRef] [PubMed]

72. Tilley, E.; Atwater, J.; Mavinic, D. Recovery of struvite from stored human urine. Environ. Technol. 2008, 29, 797-806.

73. Morales, N.; Boehler, M.; Buettner, S.; Liebi, C.; Siegrist, H. Recovery of N and P from urine by struvite precipitation followed by combined stripping with digester sludge liquid at full scale. Water 2013, 5, 1262-1278.

74. Münch, E.V.; Barr, K. Controlled struvite crystallisation for removing phosphorus from anaerobic digester sidestreams. Water Res. 2001, 35, 151-159. [CrossRef]

75. Zamora, P.; Georgieva, T.; Salcedo, I.; Elzinga, N.; Kuntke, P.; Buisman, C.J. Long-term operation of a pilot-scale reactor for phosphorus recovery as struvite from source-separated urine. J. Chem. Technol. Biotechnol. 2016, 92, 1035-1045. [CrossRef]

76. Ronteltap, M.; Maurer, M.; Gujer, W. The behaviour of pharmaceuticals and heavy metals during struvite precipitation in urine. Water Res. 2011, 41, 1859-1868.

77. Decrey, L.; Udert, K.M.; Tilley, E.; Pecson, B.M.; Kohn, T. Fate of the pathogen indicators phage $\Phi$ X174 and Ascaris suum eggs during the production of struvite fertilizer from source-separated urine. Water Res. 2011, 45, 4960-4972. 
78. Angima, S.; Noack, M.; Noack, S. Composting with Worms; Oregon State University Extension Service Seal Rock: Newport, RI, USA, 2011.

79. HomeBiogas. The HomeBiogas System. Available online: https://homebiogas.com/shop/buy-thehomebiogas-system/ (accessed on 3 September 2017).

80. Traesure. 2019, Biodigestor doméstico Compact-2. Available online: www.traesure.com/compact-2 (accessed on 11 October 2019).

81. International Energy Agency. Chile: Natural gas for 2014. Available online: https://www.iea.org/statistics/ statisticssearch/report/?year=2014\&country=Chile\&product=NaturalGas (accessed on 1 September 2017).

82. CNE. Precio Del Gas Natural; CNE: Santiago, Chile, 2017; Available online: https://www.cne.cl/estadisticas/ hidrocarburo/ (accessed on 7 February 2017).

83. Lombrices Californianas. Nuestros productos de lombricultura; lombrices-Vermicomposteras. Available online: http://lombricescalifornianas.cl/tienda/productos.html (accessed on 3 October 2017).

84. Sodimac. 2017b, Humus 3 Kilos. Available online: http://www.sodimac.cl/sodimac-cl/product/512230/ Humus-3-kilos/512230 (accessed on 3 October 2017).

85. Sodimac. 2017c, Tierra Biológica 80 Litros. Available online: http://www.sodimac.cl/sodimac-cl/product/ 462004/Tierra-biologica-80-litros/462004 (accessed on 3 October 2017).

86. Sodimac. 2017d, Bidón Plástico 25lts. Rojo. Available online: http://www.sodimac.cl/sodimac-cl/product/ 1611739/Bidon-plastico-25-litros-rojo/1611739 (accessed on 3 October 2017).

87. Sodimac. 2017a, Bidón 60 lts. Transparente. Available online: http://www.sodimac.cl/sodimac-cl/product/ 161861X/Bidon-60-1ts.-transparente/161861X (accessed on 3 October 2017).

88. Separett. 2011, Urine-diverting Product Line. Available online: http://www.urinediverting.com/index.php/ urine-diverting-product-line (accessed on 3 October 2017).

(C) 2019 by the authors. Licensee MDPI, Basel, Switzerland. This article is an open access article distributed under the terms and conditions of the Creative Commons Attribution (CC BY) license (http://creativecommons.org/licenses/by/4.0/). 